\title{
Bireysel Emeklilik Sistemi’nde Kalma Tercihini Etkileyen Faktörlerin İncelenmesi: Erzurum İl Örneği ${ }^{1}$
}

\section{Hakan ALPAĞUT ${ }^{2}$ Osman Berna İPEKTEN ${ }^{3}$}

\begin{tabular}{ccc}
\hline Geliş Tarihi// Received & Kabul Tarihi/ Accepted & Yayın Tarihi/ Published \\
10/12/2019 & $01 / 04 / 2020$ & $15 / 04 / 2020$ \\
\hline Citation/Atıf: Alpağut, H. Ve İpekten, O., B., (2020), Bireysel Emeklilik Sistemi'nde Kalma \\
Tercihini Etkileyen Faktörlerin İncelenmesi: Erzurum İl Örneği , Atatürk Üniversitesi İktisadi \\
ve İdari Bilimler Dergisi, 34(2): 461-489, DOI: $10.16951 /$ atauniiibd.657625 \\
\hline
\end{tabular}

Öz: Ülkemizde halen yürütülmekte olan Sosyal Güvenlik Sisteminin tamamlayıcısı olarak uygulanan Bireysel Emeklilik Sistemi, 18 yaşını doldurmuş olmak ve fiil ehliyetine sahip olmak koşuluyla herkesi kapsamına almaktadır. 2003 yılında uygulanmaya başlanan ve gönüllülük esasına dayanan Bireysel Emeklilik Sistemi, kişilerin kullanmadıkları gelirlerini oluşturan tasarruflarını piyasalara çekerek ülkede yapımı devam eden veya yapılması düşünülen yatırımlara kaynak sağlama imkânı sunmaktadır ve bu yönüyle finansal sistem içerisinde oldukça önemli bir rol üstlenmektedir. Roma, İlhanlı, Saltuklu, Selçuklu ve Osmanlı gibi birçok medeniyete ev sahipliği yapan Erzurum, geçmişinde olduğu gibi bugünde Anadolu coğrafyasının en gözde şehirlerinden biri konumundadır. Bu doğrultuda Erzurum insanının Bireysel Emeklilik Sistemi'ne bakış açısını yansıtmayı amaçlayan çalışma, Erzurum ilinde yaşayan ve 25-54 yaş aralığında bulunan kişileri kapsamına almaktadır. Yapılan çalışmanın temel veri toplama tekniğini kantitatif araştırma yöntemlerinden biri olan yüz yüze anket metodu oluşturmaktadır. Erzurum ilinde yaşayan ve 2554 yaş aralığında bulunan kişilerin \%81,46'sı Bireysel Emeklilik Sisteminden haberdardır ve söz konusu kişilerin \%42,95'i sisteme halen katılımcı durumundadır.

Anahtar Kelimeler: Bireysel Emeklilik Sistemi, Erzurum.

\section{Investigation of Factors That Affect the Preference of Staying in the Individual Pension System: Erzurum Case Example}

Abstract: The Individual Pension System, which is implemented as a complement to the Social Security System currently implemented in our country, covers everyone, provided that they are over 18 years of age and have the capacity to act. Initiated and voluntary Individual Pension System to be implemented in 2003, people they don't use or yielding revenue savings to be made, investments planned in the country out of the ongoing construction markets offers the possibility of providing the resource and this aspect play an important role in the financial system. Erzurum, which is home to many civilizations such as Rome, Ilhanl, Saltuklu, Seljuk and ottoman, is one of

${ }^{1}$ Bu çalışma, Dr. Öğr. Üyesi Osman Berna İPEKTEN danışmanlığında Atatürk Üniversitesi Sosyal Bilimler Enstitüsü'nde yürütülen Bireysel Emeklilik Sistemi'ne Katılım Kararını Etkileyen Faktörlerin İncelenmesi: Erzurum İli Örneği başlıklı yüksek lisans çalışmasından türetilmiştir.

${ }^{2}$ Tezli Yüksek Lisans Mezunu, Atatürk Üniversitesi, Sosyal Bilimler Enstitüsü, Muhasebe ve Finansman, https://orcid.org/0000-0002-5389-4576

${ }^{3}$ Dr. Öğr. Üyesi, Atatürk Üniversitesi, İktisadi ve İdari Bilimler Fakültesi, İşletme Bölümü, https://orcid.org/0000-0002-5105-8945 
Bireysel Emeklilik Sistemi'nde Kalma Tercihini Etkileyen Faktörlerin İncelenmesi: Erzurum Il Örneği

the favorite cities of the Anatolian geography today as it was in the past. In this respect, the study, which aims to reflect Erzurum people's perspective on the Individual Pension System, covers the people living in Erzurum and between the ages of 25-54 and the main data collection technique of the study is the face-to-face survey method, which is one of the quantitative research methods. In this context, \%81.46 of the people living in Erzurum and in the 25-54 age range are aware of the system and $\% 42.95$ of these people are still participants in the system.

Key Words: Individual Pension System, Erzurum.

\section{EXTENDED SUMMARY}

Research Problem: The Individual Pension System is implemented as a complement to the Social Security System in our country. People's savings, which make up the unused portion of their income, are transferred to markets to support investments, increase production, increase employment and contribute to the formation of new savings. In this context, the Individual Pension System assumes an important role within the financial system. This study aims to determine the state of awareness of the Individual Pension System of the people living in Erzurum and in the age range of 25-54, the state of participation in the system and the factors that ensure that they do not leave the system if they are participating in the system.

Metodology: This study is a quantitative study aimed at reflecting the perspective of individuals living in Erzurum between the ages of 25-54 to the Individual Pension System. For this reason, the most basic data providing method used in conducting the study is one of the quantitative research methods, face to face survey method. The study included 25-54 years old people living in Erzurum. In 2018, there are 291,627 people in the 25-54 age range living in Erzurum. Of these, 143,651 were women and 147,956 were men.

In the optimum sample table, the number of surveys per 291,627 people is 383. Therefore, 189 women and 194 men were surveyed by taking into consideration the population and the total number of samples.

The study categorized people into 4 groups as scope. This classification is categorized to include public sector employees, private sector employees, selfemployed and inactive people.

In this context, the distribution according to the profession for women is made up of 47 public sector employees, 47 private sector employees, 47 selfemployed professionals and 48 inactive people. Similarly, for men, it consists of 49 public sector employees, 49 private sector employees, 48 self-employed professionals, and 48 inactive pepole.

In order to determine whether the participants had an idea about Individual Pension System, the 23rd question in the questionnaire presented to the sample group was prepared. In this context, the respondents were asked where they heard about the Individual Pension System for the first time and they were given a number of options such as the circle of friends, bank, newspaper, internet. Among these options, it was thought that the people who selected the "I heard it fort he first time" option did not have the slightest knowledge of the system, and they 
were asked not to mark the remaining questions in order to prevent the formation of asymmetric information and the data from the survey form from actually moving away.

Following the completion of the face-to-face survey application, Statistical Package for the Social Sciences (SPSS) package program was used to analyze the data obtained from the respondents answers to the questions in the questionnaire submitted to the sample group. SPSS version 20.0 is preferred for entering data into to the computer. Then, graphs were created and interpreted with this data.

Findings: According to the survey results, $81.46 \%$ of the participants were aware of the Individual Pension System. Factors such as lack of follow-up of the economic situation, indifference to technology news, learning preferences, people's career or experience, education level and employment coverage play a role.

The ranking of factors that ensure that people who are currently participating in the Individual Pension System do not leave the system is as follows;

1. Government support

2. The opportunity to leave at any time

3. Change of contribution amount at any time

3. Including people who don't work

4. Provide additional income during retirement

5. Offering the possibility of retiring at an earlier age than public retirement

6. Managing savings by professionals

7. Being an ideal investment vehicle

8. Tax incentives

\section{Giriş}

İnsan yaşantısının sürdürülmesi için gereksinim duyulan ihtiyaçların karşılanması gerekmektedir. Söz konusu ihtiyaçları karşılamak için tarih boyunca çeşitli çabalar gösterilmiş ve nihayetinde hep bir takım tehlike veya risklerle karşı karşıya kalınmıştır. Bireylerin gelirlerinde azalmaya veya giderlerinde artmaya sebep olan bu durum karşısında "Sosyal Güvenlik Sistemi" oluşturulmuştur.

Genel hatlarıyla Bireysel Emeklilik Sistemi, 18 yaşını doldurmuş ve fiil ehliyetine sahip olan kişilerin tasarruflarını değerlendirebileceği özel bir emeklilik programıdır. 2003 yılından itibaren uygulama alanı bulan ve fizyolojik riskler kategorisinde yer alan yaşlılık durumuna karşı koruma sunmayı amaçlayan Bireysel Emeklilik Sistemi, 2013 yılında yapılan bir düzenleme ile katılımcılarına \%25'lik devlet desteği sunmaya başlamıştır. 2017 yılında Bireysel Emeklilik Sistemi'ne katılım düzeyinin yükselmesini sağlamak amacıyla Otomatik Katılım Sistemi devreye sokulmuştur. Otomatik Katılım Sistemi ile 45 yaşını aşmamış olmak koşuluyla 4/a ve 4/c kapsamında sosyal güvencesi bulunan Türkiye Cumhuriyeti vatandaşları sisteme dahil edilmiştir. Ülkemizde Sosyal Güvenlik Sistemi'nin alternatifi olmaktan ziyade tamamlayıcısı konumunda olan 
Bireysel Emeklilik Sistemi'nde Kalma Tercihini Etkileyen Faktörlerin İncelenmesi: Erzurum Il Örneği

Bireysel Emeklilik Sistemi isteğe bağlı olarak yürütülmektedir. Bu nedenden ötürü katılımcılar istedikleri zaman sistemden ayrılma, katkı payı ödemelerine ara verme veya katkı payı miktarını değiştirme gibi haklara sahiptirler.

Yapılan çalışmanın temel amacı, Erzurum ilinde yaşayan ve 25-54 yaş aralığında bulunan kişilerin Bireysel Emeklilik Sistemi'ne ilişkin görüşlerini tespit etmektir. Bu bağlamda, Erzurum'da yaşayan ve belirtilen yaş aralığında bulunan kişi sayısı Adrese Dayalı Nüfus Kayıt Sistemi verilerine göre 291.627'dir. Söz konusu bu kişilerin 143.651'i kadın, 147.956 kişi ise erkektir (TÜíK, t.y.).

Yapılan çalışma kapsam olarak kişileri 4 grupta sınıflandırmaktadır. $\mathrm{Bu}$ sinıflandırma; kamu kurumunda çalışanları, özel sektörde çalışanları, serbest meslek erbaplarını ve çalışmayan kişileri kapsayacak şekilde kategorize edilmiştir.

Optimum örneklem tablosuna göre 291.627 kişiden oluşan evrene isabet eden örneklem sayısı 383'tür. Nüfus dağılımı dikkate alınarak 383 kişilik örneklem grubu 189 kadın ve 194 erkeği temsil edecek şekilde oluşturulmuştur. Mesleğe göre yapılan dağılımda kadınların 47'si kamu çalışanı, 47'si özel sektör çalışanı, 47'si serbest meslek erbabı iken 48 kadın ise çalışmamaktadır. Benzer şekilde, erkeklerin 49'u kamu çalışanı, 49'u özel sektör çalışanı, 48'i serbest meslek erbabı iken 48 erkek ise çalışmamaktadır.

Yapılan çalışma nicel bir çalışmadır. Bu nedenle, araştırmanın en temel veri toplama tekniğini birincil veri toplama yöntemlerinden biri olan yüz yüze anket uygulaması oluşturmaktadır.

\section{Sosyal Güvenlik ve Bireysel Emeklilik Sistemi}

Genel hatlarıyla sosyal güvenlik kavramı; hastalık, işsizlik, analık, yaşlılık, ölüm gibi durumlarla ortaya çıkan ve kişilerin gerek sosyal gerekse de ekonomik yaşantılarını olumsuz yönde etkileyebilecek durumlara karşı, toplumun alınacak bir takım kamusal tedbirler ile kendini korumak amacıyla geliştirdiği bir savunma mekanizması olarak tanımlanabilir. Bu bağlamda sosyal güvenliğe yönelik olarak duyulan ihtiyaç, insanlığın başlangıcından beri var olmuş ve bugüne değin süre gelmiştir (Güvercin, 2004: 89,90).

18. ve 19. yüzy1llarda gerçekleşen sanayi devrimiyle endüstri toplumuna geçilmiş ve işçi sınıfi oluşmuştur. İşçi sınıfının oluşması ile beraber sosyal güvenliğe duyulan ihtiyaç daha da hissedilir hale gelmiştir. Bu durumun sonucu olarak sosyal güvenlik anlamında ilk sistem Almanya'da ortaya çıkmış ve Alman devlet adamı Bismark tarafindan sosyal sigortalar kurulmuştur. Toplumsal huzuru sağlamaya yönelik olarak kurulan bu sigortalar; hastalık sigortası, yaşlılık ve maluliyet sigortası ile iş kazaları ile ilgili sigortaları kapsamıştır (Şenocak, 2009: 419).

Sosyal güvenlik uygulaması ile, toplumun her kesimini kapsayacak şekilde; işsizlik durumunda gelir kaybının önüne geçilmesi, emekli olan insanlar için emeklilik dönemlerinde gelir elde etme imkânının sağlanması gibi olanaklar 
sunulmaktadır. Bununla birlikte küreselleşmenin etkili olduğu çağımızda ülkelerin büyüme ve gelişmelerine katkıda bulunarak sosyal açıdan bütünleşmenin sağlanması hedeflenmektedir (ILO, t.y.).

Genel hatları ile Bireysel Emeklilik Sistemi; yatırımcıların taşıdı̆g 1 özellikler, tasarrufların değerlendirilmesi, sistem bünyesinde toplanan primler ile sermaye piyasalarına uzun vadeli fon kaynağı sağlanması gibi nitelikleriyle ülkede yatırımların desteklenmesi, üretimin ve istihdamın artırılmasına katkı sunmaktadır. İşsizliğin önüne geçilmesi, yeni tasarrufların oluşmasına vesile olması gibi özellikleri dolayısıyla bazı ülkelerde sosyal güvenlik uygulamasının tamamlayıcı bir parçası konumunda iken bazı ülkelerde ise sosyal güvenlik uygulamasına alternatiftir. Dolayısı ile sisteme katılım bazı ülkelerde zorunlu iken bazı ülkelerde gönüllülük esasına dayanmaktadır (Öğütgen, 2004: 1).

Ülkemizde uygulanan Bireysel Emeklilik Sistemi, 18 yaşını dolduran, kanunlardan doğan haklarını kullanma mahiyetine sahip olan herkesi kapsamına almaktadır. 10 yıllık prim ödemesi şartıyla 56 yaşında emekli olma imkânı sunan Bireysel Emeklilik Sistemi; bireylerin yaşantılarında veya çalışma hayatlarında elde ettikleri tasarruflarını değerlendirerek, emeklilik dönemlerindeki muhtemel gelirlerine ilaveten gelir sağlamalarına katkıda bulunmayı amaçlamaktadır. Bu amaçla, bireylerin yaşam standartlarının yüksek olması için atıl durumdaki tasarrufları piyasaya aktararak değerlendirmenin sonucunda ülkede üretimin artması, işsizliğin azalması gibi toplumsal huzuru sağlamaya yönelik adımlar atmaktadır (Seyfullahoğulları ve Demirhan, 2016: 26).

Bireysel Emeklilik Sistemi, Sosyal Güvenlik Sistemi’nin alternatifi değil aksine tamamlayıcısıdır ve bu özelliğinden dolayı isteğe bağlı olarak yürütülmektedir. Dolayısıyla katılımcılar sisteme giriş yapıldıktan sonra istedikleri zaman ayrılma hakkına sahiptir. Türkiye'de 4632 sayılı Bireysel Emeklilik Tasarruf ve Yatırım Sistemi Kanunu ile düzenlenen, 2003 yılından beri faal olan ve fonlama usulüne dayalı olarak uygulaması bulunan Bireysel Emeklilik Sistemi'nde, katılımcılar tarafından yapılan katkı payı ödemeleri, yine katılımcılar tarafından seçilecek olan emeklilik yatırım fonlarında işlem görerek bir takım getiriler sağlamaktadır. Sağlanan bu getiriler ise emeklilik gelirini meydana getirmektedir (İşseveroğlu ve Hatunoğlu, 2002: 156, 157).

Bireysel Emeklilik Sistemi'ne katılan kişilere 2013 yılından itibaren yatırdıkları prim ödemelerinin $\% 25$ 'i oranında devlet desteği sunulmaktadır. Söz konusu devlet desteği, o yıl için hesaplanan brüt asgari ücretin yıllık tutarını geçmeyecek şekilde sınırlandırılmıştır. Bireysel Emeklilik Sistemi’nin isteğe bağlı olarak uygulanmasından ötürü, katılımcılar istedikleri zaman sistemden ayrılma hakkına sahiptirler. Bu bağlamda, sistemde en az 3 yılı dolduran kişiler hak ettikleri devlet desteğinin \%15'ini, sistemde en az 6 yllı dolduran kişiler hak ettikleri devlet desteğinin \%35'ini, sistemde en az 10 yılı dolduran ve 56 yaşını beklemeden çıkış yapan kişiler hak ettikleri devlet desteğinin \%60'ını alırlar. Buna karşın, 10 yıl süreli prim ödemesini yaparak 56 yaşını dolduranlar, malul 
Bireysel Emeklilik Sistemi'nde Kalma Tercihini Etkileyen Faktörlerin İncelenmesi: Erzurum Il Örneği

duruma düşenler ve vefat edenler devlet desteğinin tamamını alma hakkına sahiptirler. (EGMa, t.y.).

Katılımcılar tarafından yapılan katkı payı ödemelerinden oluşan fonlar, profesyonel olarak fon yönetimi yapan kuruluşlar tarafindan değerlendirilmektedir. Bireysel Emeklilik Sistemi'nden emekli olma imkânı elde eden kişiler, sisteme aktardıkları tasarruflarını ve bunların kazanımlarından oluşan birikimlerini; toplu olarak bir defada alma, yıllık gelir sözleşmesi kapsamında düzenli maaş ödemeleri biçiminde alma veya birikimlerinin bir kısmını toplu olarak geriye kalan kısmını maaş ödemesi olarak alma hakkına sahiptirler. Bu bağlamda, emekli olan kişilere yapılan olan maaş ödemeleri, yıllık, altı ayda bir, üç ayda bir veya aylık maaş ödemesi şeklindedir (Mizrahi ve Arac1, 2012: 43).

Bireysel emeklilik kapsamında tasarruflardan elde edilen ve sistemde oluşan birikimler, katılımcılarla ilişkilendirilmiş bireysel hesaplarda izlenir ve Sermaye Piyasası Kurulu tarafindan görevlendirilen Takasbank tarafindan saklanır. Hazine ve Maliye Bakanlığı, Sermaye Piyasası Kurulu, Emeklilik Gözetim Merkezi, Takasbank ve ismi zikredilen kurumların dışında, sistem bünyesindeki emeklilik şirketlerinde bulunan ve iç denetimi sağlamak amaciyla oluşturulan şirket örgütleri tarafından etkin ve etkili bir denetim mekanizmasının bulunması da, Bireysel Emeklilik Sistemi'nde denetime verilen önemi ve özeni göstermektedir. Bireysel emeklilik çerçevesinde katılımcılara, özellikle yatırımsal anlamda seçeneklerin sunulması, tasarruf sahiplerine yatırım seçenekleri konusunda bilgilendirme çalışmalarının yapılmasıyla tercih yapmalarının sağlanması, birikim ve emekliliğe hak kazanım aşamalarında katılımcılara bir takım vergi teşviklerinin sağlanması sistemin diğer özelliklerindendir (Şener ve Akın, 2010: 297).

\subsection{Bireysel Emeklilikte Otomatik Katılım Sistemi}

1 Ocak 2017 tarihinden beri uygulanan Otomatik Katılım Sistemi, 2016 yılında kabul edilen Bireysel Emeklilik Tasarruf ve Yatırım Sistemi Kanununda Değişiklik Yapılmasına Dair Kanun'a dayanmaktadır. Belirtilen Kanun, 45 yaşını aşmayan Türkiye Cumhuriyeti vatandaşı kişiler içerisinde bir kişi veya kuruma bağlı çalışanların Bireysel Emeklilik Sistemi'ne kayıtlarının yapılmasını öngörmektedir (Bireysel Emeklilik Tasarruf ve Yatırım Sistemi Kanununda Değişiklik Yapılmasına Dair Kanun, 2016).

Genel hatları ile Otomatik Katılım Sistemi, bireysel emekliliğe daha fazla kişinin katılmasını sağlayarak istihdam düzeyinin artmasını ve piyasalara uzun vadeli fon aktarılmasını amaçlamaktadır. Bu bağlamda, Otomatik Katılım Sistemi'ne kayıt yaptırmak zorunludur ancak bireysel emekliliğin gönüllülük esasına dayanmasından dolayı katılımcilar istedikleri zaman sistemden ayrilma hakkına sahiptir.

Otomatik Katılım Sistemi ile sisteme giren kişilerin, prime esas kazançlarının \%3'ü tutarında katkı payı ödemesi yapılmakta ve emeklilik 
fonlarında değerlendirilerek emeklilik geliri oluşmaktadır. 2 aylık cayma hakkının kullanılmaması durumunda katılımcılara bir defaya mahsus olmak üzere $1.000 \mathrm{TL}$ devlet desteği sunulmaktadır. Ayrıca bireysel emeklilikten ayrılan kişilere ilişkin yapılan devlet desteğinin hak ediliş yüzde hesabı Otomatik Katılım Sistemi için de geçerlidir. Bu bağlamda, sistemde en az 3 yılı dolduran kişiler hak ettikleri devlet desteğinin \%15'ini, sistemde en az 6 y1lı dolduran kişiler hak ettikleri devlet desteğinin \%35'ini, sistemde en az 10 y1l dolduran ve 56 yaşını beklemeden çıkış yapan kişiler hak ettikleri devlet desteğinin \%60'ını almaktadır. Buna karşın 10 yıl süreli prim ödemesini yaparak 56 yaşını dolduranlar, malul durumuna düşenler veya vefat edenler hak ettikleri devlet desteğinin tamamını almaktadır (EGMb, t.y.).

\section{Literatür Taraması}

Coşkun Özer ve Gürel (2014) tarafından yapılan çalışma kapsamında Bireysel Emeklilik Sistemi'ne devlet desteğinin etkisini araştırmak amacıyla Marmara Üniversitesi Sosyal Bilimler Meslek Yüksekokulu'nda öğrenim gören 126 öğrenciye anket uygulanmıştır. Araştırmanın sonuçlarına göre; yalnızca \%3'lük kesim Bireysel Emeklilik Sistemi'ne katılımcıdır ve \%45'lik kesim yeterli maddi gücü olmaması sebebiyle Bireysel Emeklilik Sistemi'ne katılamadığını belirtmiştir. Ayrıca kişilerin maddi durumlarındaki iyileşmeye ve devlet desteğine bağlı olarak sisteme katılım durumunun olumlu yönde seyredeceği tespit edilmiştir.

Çetin ve Sevüktekin (2015) tarafından yapılan çalışma kapsamında Bursa ilinde yaşayan kişilerin Bireysel Emeklilik Sistemi ile ilgili tutumlarını tespit etmek amacıyla 350 kişiye anket uygulanmıştır. Araştırma sonucunda; medeni durumun, risk almayı sevme durumunun, finansal bilgi düzeyinin ve kişilerin sahip oldukları gelirin yatırım/harcama oranın Bireysel Emeklilik Sistemi'ne giriş kararını etkilediği tespit edilmiştir. Bu bağlamda evli olan, finansal anlamda risk almayı seven, finansal bilgi seviyesi yüksek olan ve harcamalarının önemli bir kısmını yatırıma dönüştürebilen kişilerin Bireysel Emeklilik Sistemi'ne katılma ihtimali \%76 olarak saptanmıştır.

Çömlekçi ve Gökmen (2017) tarafindan gerçekleştirilen çalışmada Bireysel Emeklilik Sistemi'ne katılma hususunda etkili olan faktörlerin belirlenmesi ve bu faktörlerin katılımcıların demografik özelliklerine göre farklılık gösterip göstermediğinin tespit edilmesi amaçlanmıştır. Söz konusu çalışmanın evreni TR42 Bölgesi'nde yaşayan ve sisteme üye kişiler olarak belirlenmiş ve 384 kişiye anket uygulanmıştır. Uygulanan Faktör Analizine göre Bireysel Emeklilik Sistemi'ne katılma hususunda etkili olan faktörler; yatırım ve güvence, bilgi düzeyi, uzmanlık düzeyi ve gelecek kaygısıdır. Bu bağlamda, yapılan çalışma yaş, cinsiyet, çalışma yılı, gelir düzeyi gibi değişkenler ile Bireysel Emeklilik Sistemi'ne bakış açısı arasında anlamlı ilişkiler bulunduğu sonucunu ortaya çıkarmıştır. 
Bireysel Emeklilik Sistemi'nde Kalma Tercihini Etkileyen Faktörlerin İncelenmesi: Erzurum Il Örneği

Gülay, Işık ve Öztürk (2017) tarafından yapılan çalışmada Süleyman Demirel Üniversitesi bünyesinde görev yapan akademisyenlerin Otomatik Katılım Sistemi hakkındaki görüşlerini tespit edilmeye çalışılmıştır. Söz konusu araştırmaya 45 yaşın altındaki 150 kadın ve 218 erkek olmak üzere 368 akademisyen katılmıştır. Söz konusu 368 kişi içerisinde çalışmanın yapıldı $\breve{g} l$ dönemde 118 kişinin Bireysel Emeklilik Sistemi'ne katılımcı konumunda olduğu belirtilmiştir. Araştırmanın sonucunda; Süleyman Demirel Üniversitesi akademisyenlerinin, Otomatik Katılım Sistemi’nin, Sosyal Güvenlik Sistemi’nin sorunlarını hafifletip hafifletmeyeceği hususunda kararsız kalsalar da Otomatik Katılım Sistemi'nin yararlı olacağına inandıkları belirlenmiş̦tir. Ayrıca, akademik personelin Otomatik Katılım Sistemi'ne katılım hususundaki tutumlarının; cinsiyete, aylık gelire, sistem hakkındaki bilgi düzeyine bağlı olarak farklılaştığı ortaya çıkmıştır.

Gülcan (2017) çalışmasında Mehmet Akif Ersoy Üniversitesine bağlı Gölhisar ve Ağlasun Meslek Yüksekokulların Bankacılık ve Sigortacılık Programı öğrencilerinin Bireysel Emeklilik Sistemi'nin farkındalığı konusunu ele almıştır. 274 öğrenciye uygulanan anket yönteminin sonuçlarına göre; Gölhisar Meslek Yüksekokulu öğrencilerinin Bireysel Emeklilik Sistemi hakkındaki farkındalıkları ile Ağlasun Meslek Yüksekokulu öğrencilerinin sistem hakkındaki farkındalıkları arasında anlamlı bir farklılık olmadığı gözlenmiştir. Ayrıca sigortacılık mesleğine ilgi düzeyleri ile öğrencilerin Bireysel Emeklilik Sistemi hakkındaki farkındalıkları arasında anlamlı bir farklılık olduğu ancak genel not ortalaması düzeyleri ile öğrencilerin Bireysel Emeklilik Sistemi hakkındaki farkındalıkları arasında anlamlı bir farklılık olmadığı belirtilmiştir.

Kocabıyık ve Küçükçakal (2018) tarafından yapılan çalışmada otomatik katılımlı Bireysel Emeklilik Sistemi'nden ayrılanlar için ayrılma nedenlerini, sistemde kalmayı seçip devam edenler için ise kalma nedenlerini ortaya koymayı amaçlanmıştır. Çalışmanın evrenini, Isparta ilinde yaşayan, bireysel emekliliğe katılmış kamu ve özel sektör çalışanlarını kapsayacak şekilde belirlenmiştir. 463 kişiye uygulanan anket sonuçlarına göre; 203 kiși sistemde kalmış geriye kalan 260 kişi ise sistemden ayrılmıştır. Sistemden ayrılma hususunda; 10 y1llık sürenin çok uzun bulunması, prime esas kazancın \%3'ünün kesilecek olması ve birikimlerin başka yatırım araçlarına yönlendirilmesi etkenleri önemli rol oynadığı belirlenmiştir. Buna karşın, sistemden ayrılmamayı sağlayan en önemli etkenin ise devlet katkısı olduğu tespit edilmiştir.

Özlem ve Çınar (2012) tarafından yapılan çalışmada Bireysel Emeklilik Sistemi'ne ilişkin olarak akademisyenlerin görüşleri tespit edilmiştir. $\mathrm{Bu}$ doğrultuda bir vakıf üniversitesinde 77 doçent ve 212 yardımcı doçent olmak üzere 289 kişiye anket uygulanmıştır. Araştırmanın sonuçlarına göre; \%85,7'lik kesim Bireysel Emeklilik Sistemi'nden haberdardır ve söz konusu kişilerin \%37,1'i sistemden bankalar aracılığıyla haberdar olmuştur. Anket uygulamasına katılan akademisyenlerin \%42,1'i Bireysel Emeklilik Sistemi'ne kayıtlıdır ve söz 
konusu kişiler, emeklilik döneminde ek gelir sağlamak ve geleceği güvence altına almak amacıyla sisteme katılmıştır. Bireysel Emeklilik Sistemi'ne katılmayan kişiler ise bu durumun sebebi olarak; emeklilik şirketlerine güvenilmemesini ve emekli olunması durumunda yeterli birikimin sağlanamamasını göstermiştir. Ayrıca, anket uygulamasına katılan akademisyenlerin \%48,2'si bireysel emeklilikle ilgili olarak yapılan tanıtım faaliyetlerini yeterli gördüğünü belirtmiştir.

Şataf ve Yıldırım (2019) tarafından yürütülen çalışmada Bireysel Emeklilik Sisteminin tanınırlı̆g 1 ve sisteme ilişkin düşüncelerin tespit edilmesi amacıyla Ordu ilinde yaşayan 371 kişilik örneklem gruba anket uygulanmıştır. Araştırmanın sonuçlarına göre; \%61,9'luk kesim geleceğe yönelik birikim yapmak amaciyla, \%20,9'luk kesim sistemden elde edeceği geliri çocuğu veya yakını için kullanmak amacıyla, \%12,9'luk kesim ise ikinci bir emekli maaşı almak amacıyla Bireysel Emeklilik Sistemi'ne katılmıştır. Bireysel emekliliğe katılımcı olan kişilerin \%43,9'u sistemden ayrılmayı düşünmemektedir. Ayrıca yapılan çalışmada Bireysel Emeklilik Sistemi'ne katılımın önündeki en büyük engelin gelir eksikliği olduğu belirtilmiştir.

Şener ve Akın (2010) tarafından yapılan çalışmada; kişilerin Bireysel Emeklilik Sistemi'ne girişlerini etkileyen faktörlerin tespit edilmesi amaciyla farklı meslek, cinsiyet ve yaş aralığına sahip 400 kişiye anket uygulanmıştır. Araştırmanın sonuçlarına göre; ankete katılan kişilerin \%88'i sistemden haberdar olduğu ve meslek, eğitim düzeyi ve aylık gelir düzeyinin Bireysel Emeklilik Sistemi'ne giriş kararını etkilediği gözlemlenmiştir. Bu bağlamda, gelir seviyesinin ve eğitim seviyesinin yükselmesine bağlı olarak Bireysel Emeklilik Sistemi'ne katılım durumunun olumlu yönde seyrettiği tespit edilmiştir.

Tunalı (2016) çalışmasında Anadolu Üniversitesi İktisadi ve İdari Bilimler Fakültesi akademik personelinin Bireysel Emeklilik Sistemi hakkındaki görüşlerini tespit etmeye çalışmıştır. 84 akademisyene uygulanan anket çalışmasının sonuçlarına göre; ankete katılan akademisyenlerin neredeyse hepsinin sistemle ilgili yeterli bilgi düzeyine sahip olduğu ve $\% 45,2^{\prime}$ lik kesimin bireysel emekliliğe katılımcı olduğu saptanmıştır. Ayrıca, Sosyal Güvenlik Sistemi'nin ihtiyaçlarını karşılamadığını düşünen akademik personelin Bireysel Emeklilik Sistemi'ne katılmaya daha yakın olduğu tespit edilmiştir.

Uluyol (2019) çalışmasında akademisyenlerin yatırım araçlarını tanıma ve söz konusu araçlara yatırım yapma durumunu belirlemek amacıyla 30 farklı devlet üniversitesinden 653 akademisyene anket uygulamıştır. Araştırmanın sonucuna göre; ankete katılan akademisyenlerin \%61'i Bireysel Emeklilik Sistemi hakkında yeterli düzeyde bilgi sahibidir ve akademisyenlerin $\% 43,34$ 'ü sisteme yatırım yapmamıştır.

Uzun ve Aslan (2018) tarafından yapılan çalışmada Bireysel Emeklilik Sistemi ile ilgili olarak Elazığ ilinde yaşayan ve 18 yaşın üzerindeki 200 kişiye anket uygulanmıştır. Araştırmanın sonucuna göre; Bireysel Emeklilik Sistemi'ne katılmayı sağlayan en önemli 3 etken sırasıyla; emeklilik döneminde ek gelir 
Bireysel Emeklilik Sistemi'nde Kalma Tercihini Etkileyen Faktörlerin İncelenmesi: Erzurum Il Örneği

sağlama, birikim ve devlet desteği şeklindedir. Ayrıca, toplumun önemli bir kesiminin bireysel emeklilik hakkında yeteli bilgiye sahip olduğu belirtilerek sistemi talebin yetersiz olmasının, bilgi eksikliğinden veya ekonomik nedenlerden ziyade sosyo-kültürel nedenlerden kaynaklandığı saptanmıştır.

Ünal, Boz ve Ataşer (2019) tarafindan yapılan çalışmada Kütahya il merkezinde bulunan ve 17 farklı bankanın 24 şubesinde çalışan 120 kişiye anket uygulanmıştır. Anket yöntemiyle finansal okuryazarlık ile Bireysel Emeklilik Sistemi'ne katılım durumu arasındaki ilişki incelenmiştir. Araştırmanın sonucunda söz konusu banka çalışanlarının finansal okuryazarlık seviyesinin yüksek olduğu tespit edilerek; çalışanların \%65,8'inin bireysel emekliliğe katılımcı olduğu belirtilmiştir. Ayrıca Bireysel Emeklilik Sistemi'ne katılımcı olan banka çalışanlarının finansal okuryazarlık düzeyinin, Bireysel Emeklilik Sistemi'ne katılımcı olmayan banka çalışanlarına göre pozitif yönlü farklılık gösterdiği belirtilmiştir.

Yemez ve Akdoğan (2019) tarafindan yapılan çalışma kapsamında Bireysel Emeklilik Sistemi'ne katılım durumunun demografik özelliklere bağlı olarak farkl111k gösterip göstermediğini incelenmiştir. Sivas ilinde yaşayan ve 18 yaşını doldurmuş olan 430 banka müşterisine uygulanan anket sonuçlarına göre; gelir durumu yüksek olan kişilerin ve bireysel emekliliğe daha önce katılan kişilerin bireysel emekliliğe katılım hususunda diğer kişilere kıyasla daha istekli oldukları tespit edilmiştir. Ayrıca katılım bankalarını tercih eden kişilerin, ticaret bankalarını tercih eden kişilere nazaran Bireysel Emeklilik Sistemi’ne katılmaya daha istekli oldukları belirlenmiştir.

Diğer çalışmalarda incelendiğinde, literatürde Bireysel Emeklilik Sistemi ile ilgili olarak yapılan çalışmaların fazlalığı göze çarpmaktadır. Literatürde bulunan çalışmalar genel olarak akademisyenleri, öğrencileri veya il bazında 18 yaşın üzerindeki herkesi evren kabul ederek yapılmıştır. Herhangi bir yaş aralığında bulunan kişileri kapsayan ve çalışma durumlarına göre sınırlandıran çalışmaların nadir olmasından ötürü yapılan çalışma önemlidir. Bu bağlamda yapılan çalışma; evreni 25-54 yaş aralığında bulunan kişilerle sınırlandırılması ve örneklem grubunun kamu çalışanlarını, özel sektör çalışanlarını, serbest meslek erbaplarını ve çalışmayan kişileri eşit düzeyde temsil edecek şekilde oluşturulması yönüyle özgün bir çalışmadır.

\section{Araştırmanın Bulguları}

Yürütülen çalışma kapsamında anket formunu dolduran örneklem gruba çalışanın amacı anlatılarak, kendilerinden kimlik ve iletişim bilgilerinin istenmeyeceği belirtilmiştir. Ayrıca çalışmanın sonucunda elde edilecek verilerden yalnızca bilimsel çalışmalarda yararlanılacağı hususu özellikle vurgulanmıştır.

Yürütülen yüz yüze anket uygulamasının gerçekleştirilmesinin ardından, örneklem gruba sunulan anket formundaki sorulara katılımcıların verdikleri cevaplardan elde edilen verilerin analizi için Statistical Package for the Social 
Sciences (SPSS) paket programı kullanılmış ve SPSS 20.0 sürümü tercih edilmiştir.

Erzurum'da yaşayan ve 25-54 yaş aralığında bulunan kişilerin örneklem grup çerçevesinde sisteme ilişkin görüşleri ve sisteme halen katılımcı olan kişilerin bireysel emeklilikten ayrılmamalarını sağlayan etkenlere ilişkin tepkileri bu başlık altında anlatılacaktır.

\subsection{Bireysel Emeklilik Sistemi'nin Tanınırlığına İlișkin Bulgular}

Ankete katılan kișilere, araştırmanın konusunu oluşturan Bireysel Emeklilik Sistemi'ni ilk defa nereden duydukları sorulmuş ve bu soru yardımı ile örneklem grubun sistemden haberdar olma durumu ölçülmeye çalışılmıştır. Ankete katılan kişilerden alınan cevaplar doğrultusunda aşağıdaki grafik oluşturulmuştur.

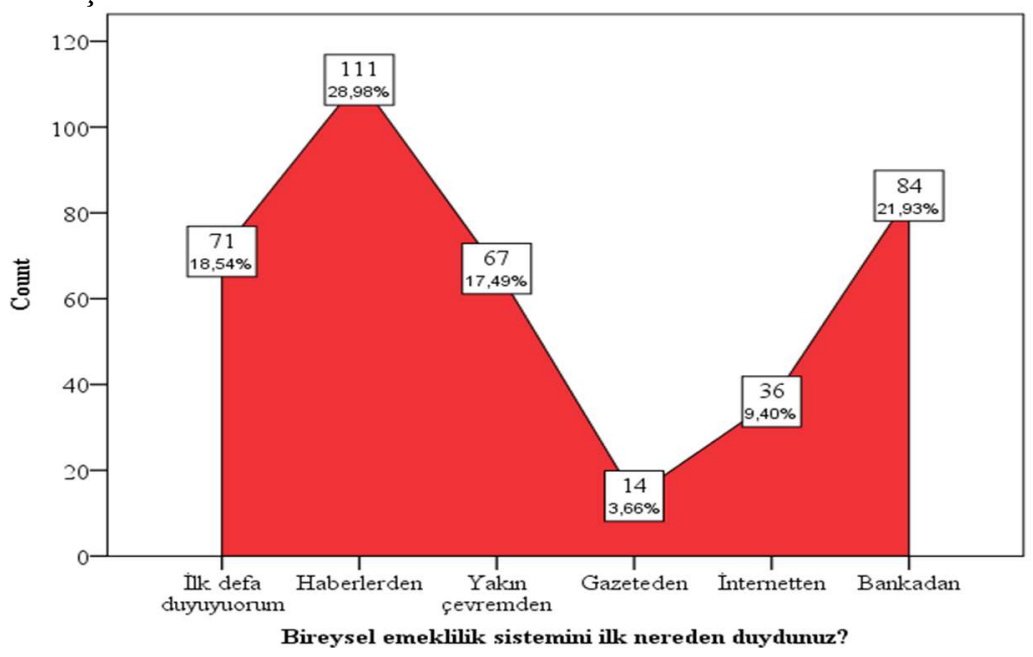

Şekil 1. Bireysel Emeklilik Sistemi'ni Tanıma Durumu.

Grafiğe göre; \%28,98'lik kesim sistemi haberlerden duyduğunu, \%21,93'lük kısım sistemi bankalardan duyduğunu, \%17,49'lık kesim sistemi yakın çevresinden duyduğunu, \%9,4'lük kesim sistemi internet ortamından öğrendiğini, \%3,66’lık kesim sistemi ilk defa gazete aracılığıyla öğrendiğini ve geri kalan \%18,54'lük kesim ise sistemi ilk defa duyduğunu ifade etmiştir.

Bundan sonraki başlıklarda ifade edilecek olan bulgular yalnızca Bireysel Emeklilik Sistemini herhangi bir yerden duymuş olan veya tanıyan kişilerin cevapları doğrultusunda incelenecektir.

\subsection{Bireysel Emeklilik Sistemi ile Gelecek Arasındaki İlișkiye İlişkin Bulgular}

Daha önce de belirtildiği gibi Bireysel Emeklilik Sistemi uygulamasının faydalarından biri de, kişilere yaşlılık dönemlerinde veya emeklilik dönemlerinde ek bir gelir sağlamasıdır. Bundan ötürü ankete katılan kişilere bireysel emeklilik 
Bireysel Emeklilik Sistemi'nde Kalma Tercihini Etkileyen Faktörlerin Incelenmesi: Erzurum Il Örneği

ile gelecek kaygısının azalacağı varsayımı hakkındaki görüşleri sorulmuş ve onlardan alınan cevaplar doğrultusunda aşağıdaki grafik oluşturulmuştur.

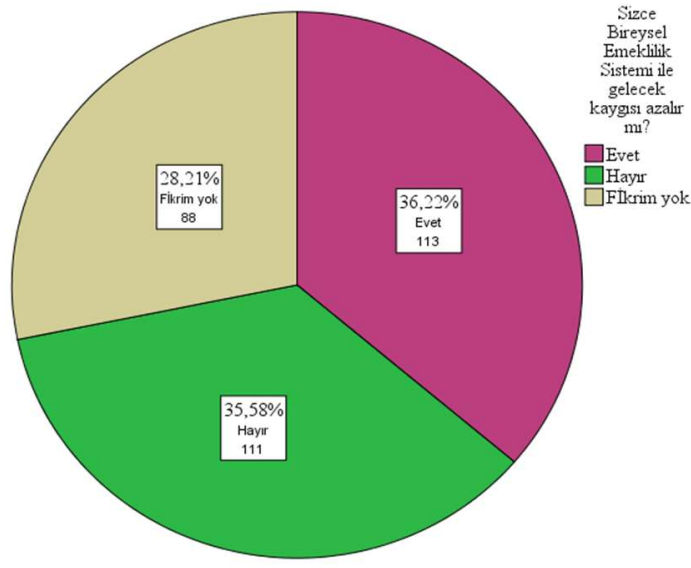

Şekil 2. Bireysel Emeklilik Sistemi ile Gelecek Kaygısı Arasındaki İlişki.

Örneklem grup içerisinde bireysel emeklilik uygulamasından haberdar olan kişilerin \%36,22'si sistemin gelecek kaygısını azaltmaya fayda sağlayacağını düşünürken, \%35,58'lik kısım gelecek kaygısının azalmayacağını ve geri kalan \%28,21'lik kısım ise konu hakkında fikrinin olmadığını belirtmiştir.

3.3. Bireysel Emeklilik Sistemi'ne Katılım Durumuna İlişkin Bulgular

Anket çalışmasına katılan kişiler içerisinde, Bireysel Emeklilik Sistemi'nden haberdar olan kişilere sisteme katılım durumları sorulmuş ve onların verdikleri cevaplar doğrultusunda aşağıdaki grafik oluşturulmuştur.

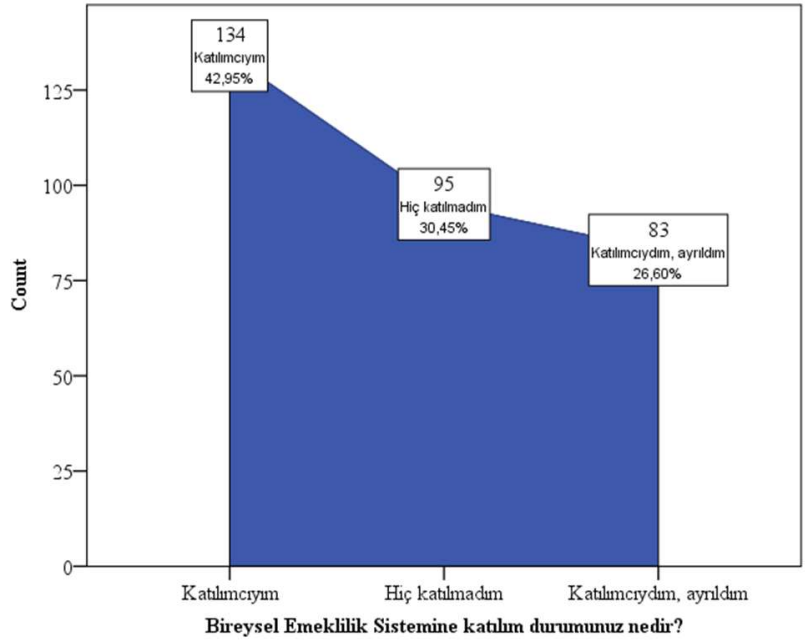

Şekil 3. Bireysel Emeklilik Sistemi’ne Katılım Durumuna İlişkin Bulgular. 
Bireysel Emeklilik Sistemi'ni tanıyan kişiler içerisinde \%42,95'lik kısım sistemde varlı̆̆ını sürdürürken, \%26,6'lık kısım sisteme katılmış ve ayrılmış, geri kalan \% 30,45'lik kesim ise, sisteme hiç katılmamışır. Başka bir ifade ile sistemi tanıyan kişiler içerisinde \%69,55'lik kesim ayrılma durumu gözetilmeksizin Bireysel Emeklilik Sistemi’nden faydalanmıştır.

\subsection{Bireysel Emekliliğe Katılım Şekline İlişkin Bulgular}

Bireysel Emeklilik Sistemi’nin gönüllülük arz ettiği ve herhangi bir kişi veya kuruma bağlı çalışıp gerekli şartları taşıyan kişilerin Otomatik Katılım Sistemi ile sisteme dahil edildikleri daha önce belirtilmişti. Bu bağlamda, örneklem grup içerisinde Bireysel Emeklilik Sistemi'nde varlığını sürdüren kişilerin hangi yolla sisteme girmiş olduklarını tespit etmek amacıyla bir soru sorulmuş ve alınan cevaplar yardımıyla aşağıdaki grafik oluşturulmuştur.

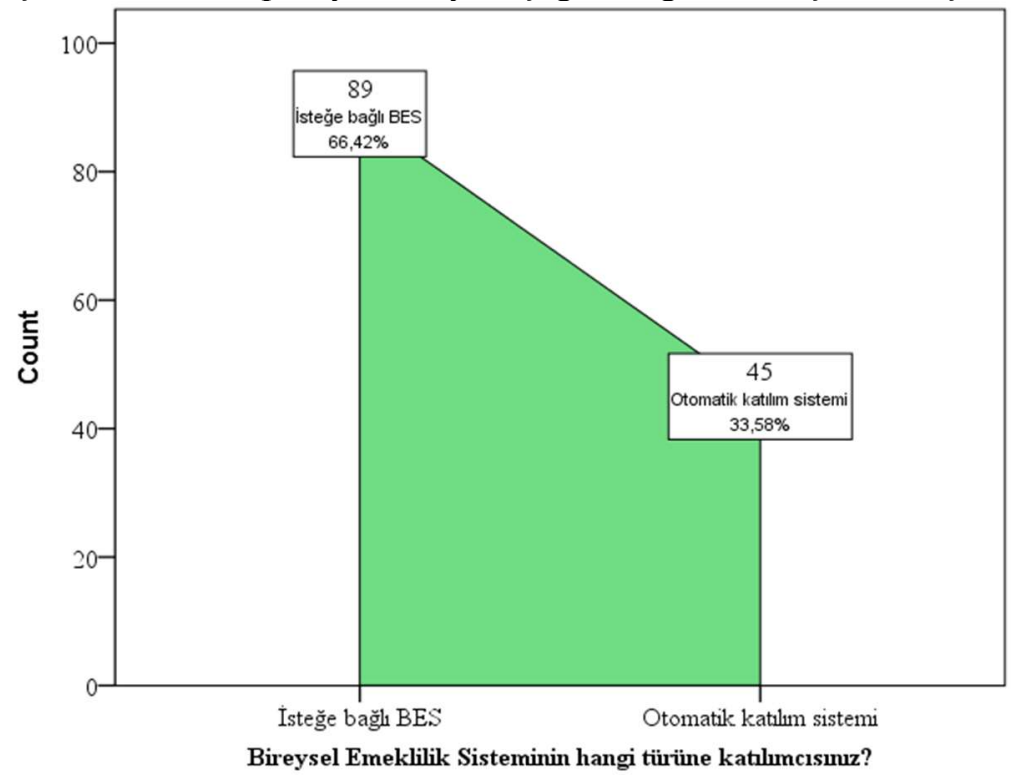

Şekil 4. Katıllmcı Olunan Bireysel Emeklilik Türü.

Grafik üzerinde de görülebileceği gibi, Bireysel Emeklilik Sistemi'nden haberdar olan ve sisteme katılan kişiler içerisinde; \%66,42'lik kesimin sisteme katılma yolu isteğe bağlı bireysel emeklilik iken geri kalan \%33,58'lik kesimin sisteme katılma yolu Otomatik Katılım Sistemidir.

\subsection{Katılımcıların Sistemden Ayrılma Düşüncesine İlişkin Bulgular.}

Örneklem guruba sunulan anket formunda, sistemde yer alan katılımcilara, sisteme girdikleri dönemden bu yana bireysel emeklilikten ayrılmayı düşünüp düşünmedikleri sorulmuş ve verdikleri cevaplar neticesinde aşağıdaki grafik oluşturulmuştur. 
Bireysel Emeklilik Sistemi'nde Kalma Tercihini Etkileyen Faktörlerin İncelenmesi: Erzurum Il Örneği

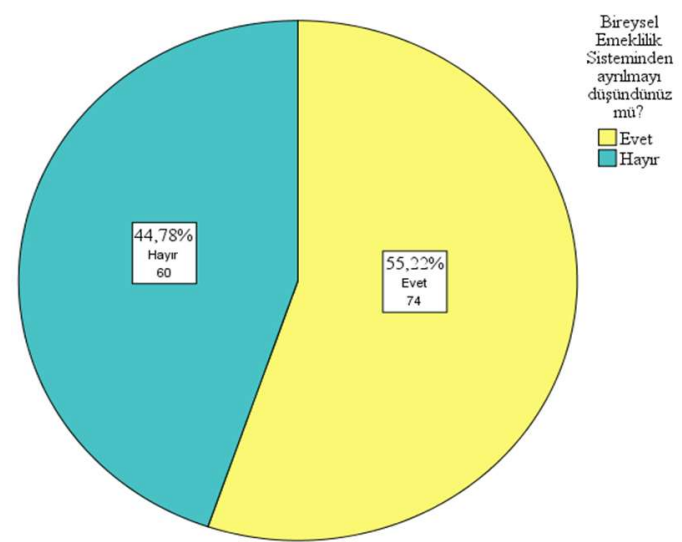

Şekil 5. Aktif Katılımcıların Sistemden Ayrılma Konusundaki Düşünceleri.

Olușturulan grafikten de anlașlabileceği üzere, bireysel emekliliğe halen katılımcı olan kişilerin \%55,22'si sistemden ayrılmayı düşünmüşken, geri kalan \%44,78'lik kısım sistemden ayrılmayı düşünmemiştir.

3.6. Bireysel Emeklilik Sistemi’ne Halen Katılımcı Olan Kişilerin Sistemden Ayrılmamalarını Sağlayan Etkenlere Illişkin Görüşleri

Örneklem grup içerisinde Bireysel Emeklilik Sistemi’nde halen katılımcı olarak yer alan kişilerin sistemden ayrılmamalarını sağlayan faktörler bir soru altında farklı seçenekler halinde sorulmuş ve analiz edilmiştir. Elde edilen veriler, oluşturulan grafikler ve analiz sonuçları anket formunda yer alan seçeneklere göre ayrı alt başliklar halinde incelenecektir.

3.6.1. Ideal Bir Yatırım Aracı Olmasına İlişkin Bulgular

Bireysel Emeklilik Sistemi’ne halen katılımcı olan kişilerin sistemden ayrılmamalarını sağlayan etkenler içerisinde Bireysel Emeklilik Sistemi'nin ideal bir yatırım olması seçeneğine ilişkin tepkileri doğrultusunda aşağıdaki grafik oluşturulmuştur.

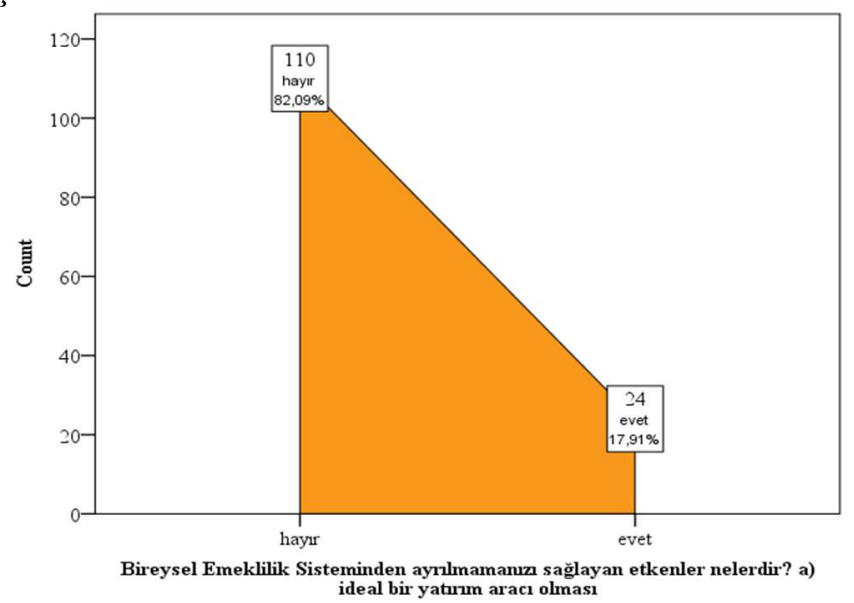

Şekil 6. Bireysel Emeklilik Sistemi’nin Yatırım Aracı Olarak Değerlendirilmesi. 
Bireysel Emeklilik Sistemi'nde halen katılımcı olan kişilerin \%82,09'u sistemi ideal bir yatırım aracı olarak görmezken, geri kalan \%17,91'lik kesim sistemi ideal bir yatırım aracı olarak görmektedir.

3.6.2. Devlet Katkısının Bulunmasına İlişkin Bulgular

Bireysel Emeklilik Sistemi'ne katılımcı olan kişilerin, sistemden ayrılmamalarını sağlayan etkenler içerisinde devlet katkısının bulunması seçeneğine ilişkin tepkileri doğrultusunda aşağıdaki grafik oluşturulmuştur.

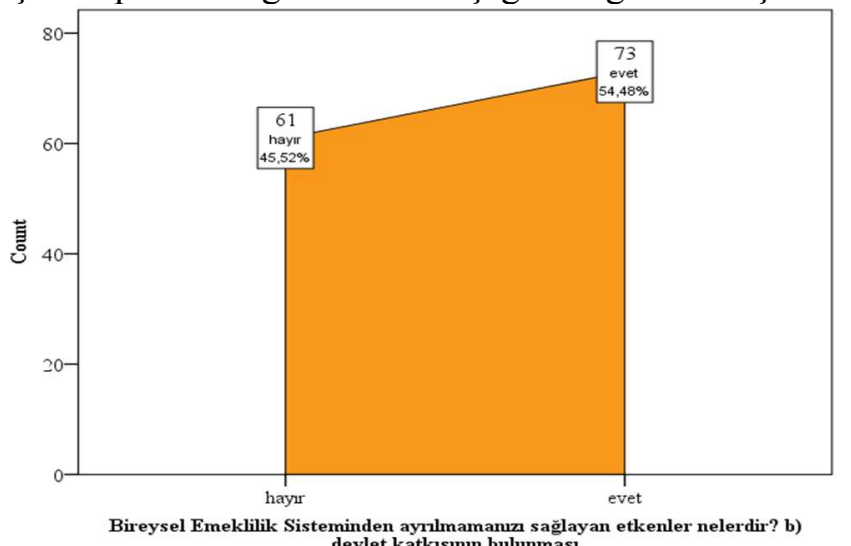

Şekil 7. Katılımcıların Devlet Desteği Hakkındaki Görüşleri.

Bireysel Emeklilik Sistemi'nde halen katılımc1 olan kişilerin \%54,48'i devlet desteğini sistemden ayrılmamayı sağlayan bir etken olarak görürken, \%45,52'lik kesim ise devlet desteğini sistemden ayrılmamayı sağlayacak önemli bir etken olarak görmemektedir.

3.6.3. Vergi Teşviklerine iliş̧kin Bulgular

Bireysel Emeklilik Sistemi katılımcılarının, sistemden ayrılmamalarını sağlayan etkenler içerisinde vergi teşvikleri seçeneğine ilişkin tepkileri doğrultusunda aşağıdaki grafik oluşturulmuştur.

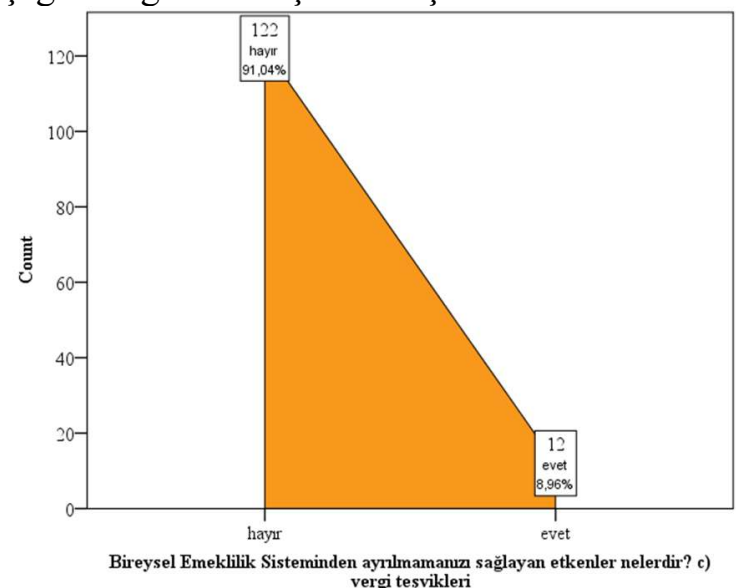

Şekil 8. Bireysel Emekliliğe Katılımcı Olanların Vergi Teşvikine İlişkin Görüşleri. 
Bireysel Emeklilik Sistemi'nde Kalma Tercihini Etkileyen Faktörlerin İncelenmesi: Erzurum Il Örneği

Bireysel Emeklilik Sistemi'nde katılımcı olan kişilerin \%8,96'sı vergi teşviklerini sistemden ayrılmamayı sağlayan bir etken olarak görürken, geri kalan \%91,04'lük kesim ise vergi teşviklerini sistemden ayrılmamayı sağlayacak önemli bir etken olarak görmemektedir.

3.6.4. Sistemden Ayrllma Esnekliğine İlişkin Bulgular

Bireysel Emeklilik Sistemi katılımcılarının, sistemden ayrılmamalarını sağlayan etkenler içerisinde, sistemin isteğe bağlı olarak yürütülmesinin tezahürü olan istenildiği zaman ayrlma durumuna ilişkin tepkilerinden hareketle aşağıdaki grafik oluşturulmuştur.

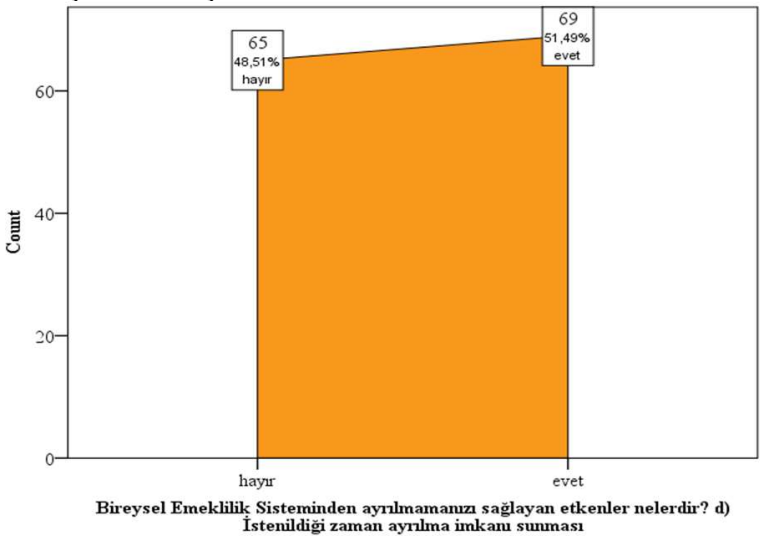

Şekil 9. Katıllmcıların Sistemden Ayrllma Esnekliğine Verdiğgi Tepkiler.

Bireysel Emeklilik Sistemi'nde halen katılımcı olan kişiler için sistemden istenildiği zaman ayrılma esnekliği \%51,49'luk kesim için önemli bir etken iken, geri kalan \%48,51'lik kesim için ise önemli bir etken değildir.

3.6.5. Emeklilik Döneminde Ek Gelir Sağlamasına İlişkin Bulgular

Bireysel Emeklilik Sistemi katılımcılarının, sistemden ayrılmamalarını sağlayan etkenler içerisinde emeklilik döneminde ek bir gelir sağlama durumuna ilişkin tepkileri doğrultusunda aşağıdaki grafik oluşturulmuştur.

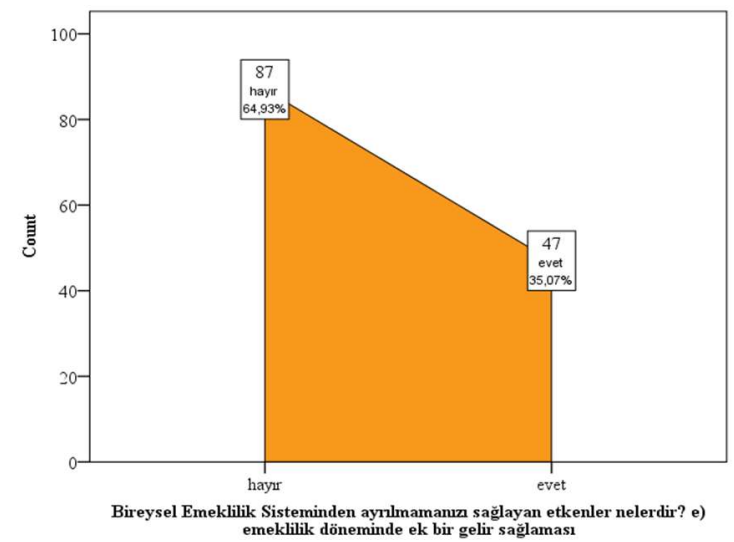

Şekil 10. Emeklilik Döneminde Ek Gelir Sağlamasına İlişkin Bulgular. 
Bireysel Emeklilik Sistemi'ndeki katılımcıların \%35,07'si emeklilik dönemlerinde ek bir gelir sağlamayı önemli görürken, geri kalan \%64,93'lük kesim ise önemli bir etken olarak görmemektedir.

3.6.6. Çalışmayan Kişileri de Kapsaması Durumuna İlişkin Bulgular

Bireysel Emeklilik Sistemi katılımcılarının, sistemden ayrılmamalarını sağlayan etkenler içerisinde sistemin çalışmayan kişileri de kapsaması durumuna ilişkin tepkileri grafikteki gibidir.

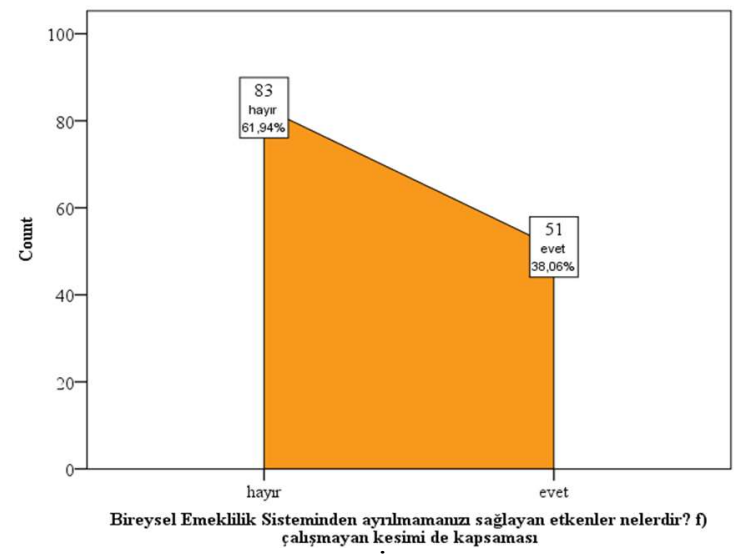

Şekil 11. Bireysel Emekliliğin Çalıșmayan İnsanları da Kapsamasına Verilen Tepkiler.

Söz konusu durum yüzdesel olarak ifade edilmek istenirse, Bireysel Emeklilik Sistemi'nde katılımcı olan kişiler için, sistemin çalıșmayan kișileri de kapsaması özelliği sistemde kalma tercihinde \%38,06’l1k kesim için önemli bir etken iken, geri kalan \%61,94'lük kesim için ise belirtilen seçenek önemli bir etken değildir.

3.6.7. Katkı Payı Miktarının İstenildiği Zaman Değiş̧tirilmesi Durumuna İlişkin Bulgular

Bireysel Emeklilik Sistemi'nde katılımcı olarak sistemde yer alan kişilerin sistemden ayrılmamalarını sağlayan etkenler içerisinde katkı payı miktarının istenildiği zaman değiştirilmesi durumuna ilişkin tepkileri doğrultusunda aşağıdaki grafik oluşturulmuştur. 
Bireysel Emeklilik Sistemi'nde Kalma Tercihini Etkileyen Faktörlerin İncelenmesi. Erzurum Il Örneği

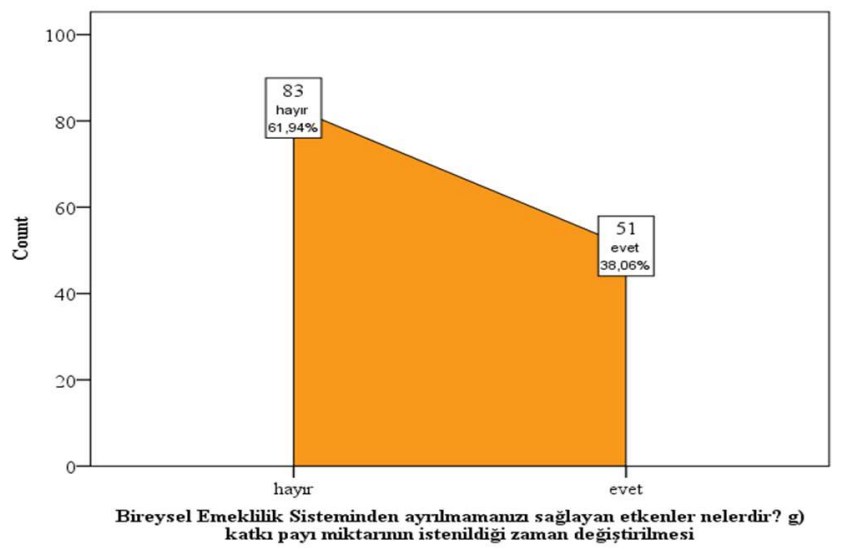

Şekil 12. Katılımcıların Katkı Payının İstenildiği Zaman Değisştirilmesine Verdiği Tepkiler.

Bireysel Emeklilik Sistemi'nde katılımcı olan kişiler için, katkı payı ödemelerinin istenildiği zaman değiştirilmesi \%38,06’lık kesim için önemli bir etken iken, \%61,94'lük kesim için ise önemli bir etken değildir.

\subsubsection{Kamusal Emekliliğe Göre Daha Erken Emeklilik Avantajına Yönelik Bulgular}

Bireysel Emeklilik Sistemi, 10 yıllık prim ödemesi şartını tamamlayan kişilere 56 yaşında emekli olma imkânı sunmaktadır. Kamusal emeklilik sisteminde ise emekli olmak için 65 yaş şartı bulunmaktadır. Bu doğrultuda örneklem grubu içerisinde sisteme halen katılımcı olan kişilerin söz konusu duruma verdikleri tepkiler neticesinde aşağıdaki grafik oluşturulmuştur.

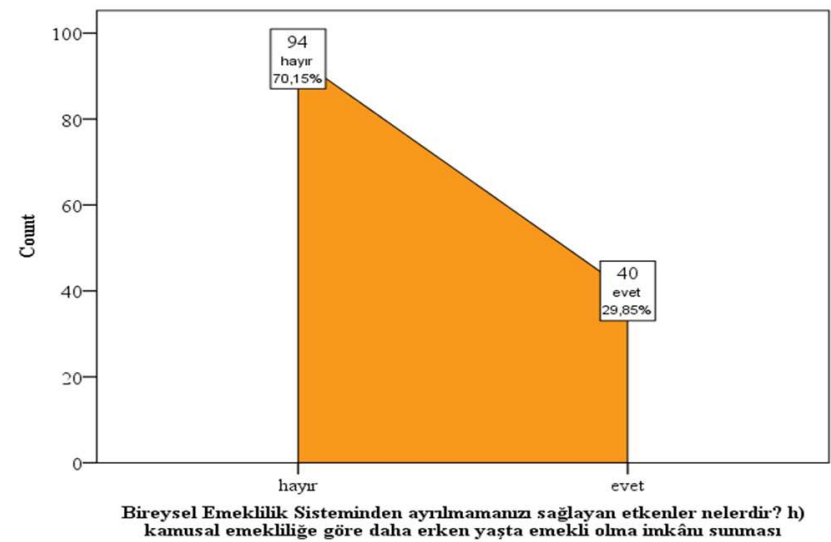

Şekil 13. Katılımcıların Erken Emeklilik Avantajına Verdiği Tepkiler.

Bireysel Emeklilik Sistemi’nde halen katılımcı olan kișiler için sistemin kamusal emekliliğe göre daha erken yaşta emeklilik sunması hususu sistemde kalma tercihinde \%29,85'lik kesim için önemli bir etken iken, geri kalan \%70,15'lik kesim için ise belirtilen seçenek önemli bir etken değildir. 


\subsubsection{Tasarrufların Uzman Kişiler Tarafindan Yönetilmesine İlişkin Bulgular}

Bireysel Emeklilik Sistemi kapsamında biriken fonlar, uzman kişiler tarafindan sistemde yer alan katılımcıların tercihleri doğrultusunda emeklilik fonlarında yönetilir. $\mathrm{Bu}$ doğrultuda örneklem grubu içerisinde halen sisteme katılımcı olan kişilerin söz konusu seçeneğe vermiş oldukları tepkiler neticesinde aşağıdaki grafik oluşturulmuştur.

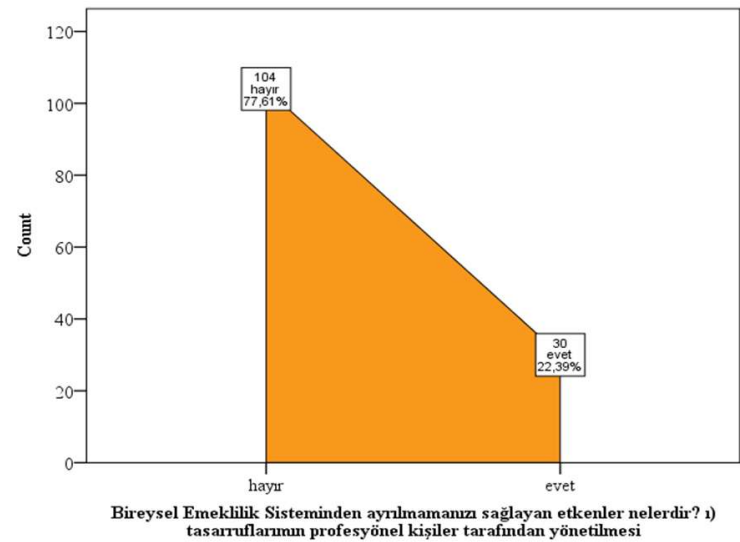

Şekil 14. Katılımcıların Tasarruflarının Uzman Kişiler Tarafından Yönetilmesi Durumuna Verdiği Tepkiler.

Bireysel Emeklilik Sistemi'nde katılımcılar için sisteme aktarılan fonların uzman kişiler tarafindan yönetilmesi hususu; sistemde kalma tercihinde \%22,39'luk kesim için önemli bir etken iken, geri kalan \%77,61'lik kesim için etken değildir.

Elde edilen verilere göre Bireysel Emeklilik Sistemi'nde varlığını sürdüren kişiler için, sistemden ayrılmamalarını sağlayan etkenler önem sırasına göre şöyledir;

1. Devlet desteğinin bulunması $(\% 54,48)$

2. İstenildiği zaman ayrılma imkânı sunması $(\% 51,49)$

3. Katkı payı miktarının istenildiği zaman değiştirilmesi $(\% 38,06)$

3. Çalı̧̧mayan kesimi de kapsaması $(\% 38,06)$

4. Emeklilik döneminde ek bir gelir sağlaması $(\% 35,07)$

5. Kamusal emekliliğe göre daha erken yaşta emekli olma imkânı sunması $(\% 29,85)$

6. Tasarrufların profesyonel kişiler tarafından yönetilmesi $(\% 22,39)$

7. İdeal bir yatırım aracı olması $(\% 17,91)$

8. Vergi teşvikleri $(\% 8,96)$

\section{Araştırmanın Hipotezleri}

$\mathrm{Bu}$ başlıkta; Erzurum'da yaşayan ve 25-54 yaş aralığında bulunan kişilerin Bireysel Emeklilik Sistemi'ne katılım durumları cinsiyet, meslek, yaş grubu, eğitim seviyesi ve medeni durum bazında incelenecek, daha sonra 
Bireysel Emeklilik Sistemi'nde Kalma Tercihini Etkileyen Faktörlerin İncelenmesi. Erzurum Il Örneği

belirtilen değiş̧kenlere ilişkin olarak kurulan hipotezler Ki-Kare Testi aracılığıyla sinanacaktır.

4.1. Ki-Kare Testi

Genel olarak Ki-Kare Testi, sınıflara ayrılmış, adlandırılmış veya kategoriler ile ifade edilmiş veriler üzerinde yapılan ve iki farklı değişken üzerine kurulan frekansları içeren istatistiksel bir testtir (Curtis ve Youngquist, 2013: 179). Ki-Kare yöntemi ile analizi yapılan bağımsızlık testleri genel olarak $2 \times 2$ veya satır ve sütun sayısının 2'den büyük olduğu boyutlara sahip olan tablolar aracılı̆̆ıyla yapılır. SPSS uygulamasında oluşturulan Ki-Kare değerleri ikiden fazla kategoriye sahip değişkenler arasında uygulanıyorsa, yani tablo oranı $2 \times 2$ 'den büyük ise bu durumda oluşturulan tabloda bulunan hücre frekansının 5 sayısından büyük olması istenilmektedir. Şayet oluşturulan frekans tablolarında 5 'ten küçük olan hücrelerin sayıs $\% 20$ 'den küçük ise Pearson Ki-Kare testi değerine, eğer frekans değeri 5 'ten küçük olan hücrelerin sayıs $\% 20$ 'den büyük ise, Fisher Exact Testi değerine bakılır. Bakılan test değerleri eğer \%5'ten küçük ise değişkenler arasında ilişki olduğu, \%5' den büyük ise değişkenler arasında ilgi olmadığı sonucuna varılır (Çolak, 2014).

\subsection{H1: Bireysel Emeklilik Sistemi'ne Katılım Durumu Cinsiyet ile İlgilidir}

Bireysel Emeklilik Sistemi'ne katılım durumunun, cinsiyete bağlı olup olmadığını anlamak için kurulan bu hipoteze ait $\mathrm{H}_{0}$ ve $\mathrm{H}_{1}$ hipotezleri, çapraz tablo ve Ki-Kare Testi tablosu şöyledir;

$\mathrm{H}_{0}$ : Değişkenler arasında ilişki yoktur.

$\mathrm{H}_{1}$ : Değişkenler arasında ilişki vardır.

Tablo 1. Cinsiyete Göre Bireysel Emeklilik Sistemi'ne Katıllm Durumu.

\begin{tabular}{|l|l|l|l|l|l|}
\hline \multicolumn{2}{|c|}{} & \multicolumn{3}{|c|}{ Bireysel Emeklilik Sistemi’ne katılım durumunuz } & \multirow{2}{*}{ nedir? } \\
\cline { 3 - 6 } & & Katılımcıyım & $\begin{array}{c}\text { Hiç } \\
\text { katılmadım }\end{array}$ & $\begin{array}{c}\text { Kat1lmcıydım, } \\
\text { ayrıldım }\end{array}$ & \\
\hline $\begin{array}{l}\text { Cinsiyetiniz } \\
\text { nedir? }\end{array}$ & ERKEK & 67 & 51 & 45 & 163 \\
\cline { 2 - 5 } & KADIN & 67 & 44 & 38 & 149 \\
\hline Total & 134 & 95 & 83 & 312 \\
\hline
\end{tabular}

Bireysel Emeklilik Sistemi'ni tanıyan 163 kişilik erkek grubu içerisinde; 67 kişi sistemde kalmayı sürdürürken, 45 kişi katılıp daha sonra ayrılmış ve 51 kişi ise sisteme hiç katılmamıştır.

Bireysel Emeklilik Sistemi’ni tanıyan 149 kişilik kadın grubu içerisinde; 67 kişi sistemde kalmaya devam ederken, 38 kişi katılıp daha sonra ayrılmış ve 44 kişi ise sisteme hiç katılmamıştır. 
Tablo 2. Cinsiyete Göre Bireysel Emeklilik Sistemi'ne Katılım Durumu Ki-Kare Testi.

\begin{tabular}{|c|c|c|c|}
\hline & Value & Df & Asymp. Sig. (2-sided) \\
\hline Pearson Chi-Square &, $479^{\mathrm{a}}$ & 2 &, 787 \\
\hline Likelihood Ratio & ,479 & 2 & ,787 \\
\hline Linear-by-Linear Association & ,413 & 1 &, 520 \\
\hline $\mathrm{N}$ of Valid Cases & 312 & & \\
\hline
\end{tabular}

a. 0 cells $(0,0 \%)$ have expected count less than 5 . The minimum expected count is 39,64 .

Tablo 2'de gösterilen Ki-Kare Testi sonucuna göre 5'ten küçük olan hücre bulunmamaktadır, dolayısıyla bu durumda Pearson Ki-Kare değerine bakılır. Söz konusu hipotez için var olan Pearson Ki-Kare anlamlılık değeri ise 0,787'dir ve bu değer, olması gereken 0,05 'lik değerden büyük olduğu için bu iki değişken arasında bir ilgi ilişkisi yoktur. Bu nedenden ötürü, $\mathrm{H}_{0}$ hipotezi kabul edilir.

4.3. H2: Bireysel Emeklilik Sistemi'ne Katılım Durumu Meslek ile İlgilidir.

Kişilerin mesleklerine göre Bireysel Emeklilik Sistemi’ne katılım durumunu ifade eden çapraz tablo, kurulan $\mathrm{H}_{0}$ ve $\mathrm{H}_{1}$ hipotezleri ile Ki-Kare Testi tablosu şöyledir;

$\mathrm{H}_{0}$ : Değişkenler arasında ilişki yoktur.

$\mathrm{H}_{1}$ : Değişkenler arasında ilişki vardır.

Tablo 3. Mesleğe Göre Bireysel Emeklilik Sistemi'ne Katılım Durumu.

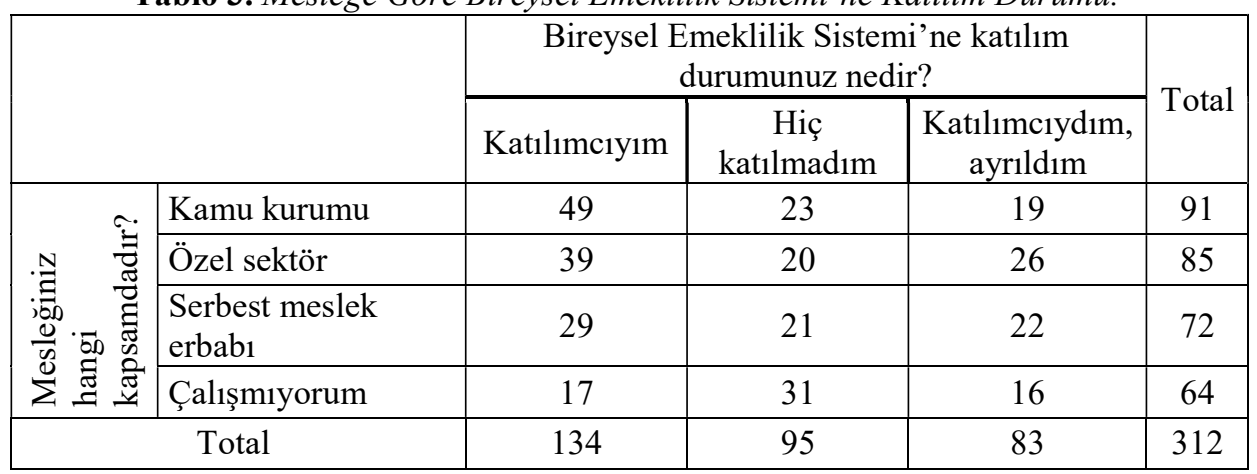

Bireysel Emeklilik Sistemi'nden haberdar olan 312 kişi içerisinde; 91 kişi kamu kurumunda çalışırken, 85 kişi özel sektörde çalışmakta, 72 kişi serbest meslek erbabı olarak çalışmakta ve geri kalan 64 kişi ise herhangi bir işte çalışmamaktadır. Belirtilen mesleklere göre Bireysel Emeklilik Sistemi'ne katılım durumu şöyledir;

Kamu kurumunda çalışan 91 kişi içerisinde; 49 kişi sistemde kalmayı sürdürürken, 19 kişi sisteme katılmış ve daha sonra sistemden ayrılmış, 23 kişi sisteme hiç katılmamıştır.

Özel sektörde çalışan 85 kişi içerisinde; 39 kişi sistemde kalmayı sürdürürken, 26 kişi sisteme katılmış ve daha sonra sistemden ayrılmış, 20 kişi sisteme hiç katılmamıştır. 
Bireysel Emeklilik Sistemi'nde Kalma Tercihini Etkileyen Faktörlerin İncelenmesi: Erzurum Il Örneği

Serbest meslek erbabı olan 72 kişi içerisinde; 29 kişi sistemde kalmayı sürdürürken, 22 kişi sisteme katılmış ve daha sonra sistemden ayrılmış, 21 kişi sisteme hiç katılmamıştır.

Herhangi bir işte çalışmayan 64 kişi içerisinde; 17 kişi sistemde kalmayı sürdürürken, 16 kişi sisteme katılmış ve daha sonra sistemden ayrılmış, 31 kişi sisteme hiç katılmamıştır.

Tablo 4. Mesleğe Göre Bireysel Emeklilik Sistemi’ne Katılım Durumu Ki-Kare Testi.

\begin{tabular}{|l|r|r|r|}
\hline & Value & Df & Asymp. Sig. (2-sided) \\
\hline Pearson Chi-Square & $17,897^{\mathrm{a}}$ & 6 &, 006 \\
Likelihood Ratio & 17,511 & 6 &, 008 \\
Linear-by-Linear Association & 5,896 & 1 &, 015 \\
N of Valid Cases & 312 & & \\
\hline
\end{tabular}

a. 0 cells $(0,0 \%)$ have expected count less than 5 . The minimum expected count is 17,03.

Tablo 4 üzerinde gösterilen Ki-Kare Testi sonucuna göre hiçbir hücrenin değeri 5'ten küçük değildir ve bu durumda Pearson Ki-Kare anlamlılık değerine bak1lır. Ki-Kare tablosunda Pearson Ki-Kare değerine isabet eden 0,006 değeri 0,05 'ten küçük olduğu için, $\mathrm{H}_{0}$ hipotezi reddedilir. Bu nedenle Bireysel Emeklilik Sistemi'ne katılım durumunun meslek ile ilgili olduğu gözlenmiştir.

4.4. H3: Bireysel Emeklilik Sistemi'ne Katılım Durumu Yaş Grubu İle İlgilidir.

Bireysel Emeklilik Sistemi'ne katılım durumu ve yaş grubu arasındaki ilişkiyi ifade eden çapraz tablo şöyledir;

Tablo 5. Yaş Grubuna Göre Bireysel Emekliliğe Katılım Durumu.

\begin{tabular}{|l|l|r|r|r|r|}
\hline \multirow{2}{*}{} & \multicolumn{4}{|c|}{$\begin{array}{c}\text { Bireysel Emeklilik Sistemi'ne katılım } \\
\text { durumunuz nedir? }\end{array}$} & \multirow{2}{*}{ Total } \\
\cline { 3 - 6 } & Katılımcıyım & $\begin{array}{c}\text { Hiç } \\
\text { katılmadım }\end{array}$ & $\begin{array}{c}\text { Katılımcıydım, } \\
\text { ayrıldım }\end{array}$ & \\
\hline \multirow{3}{*}{$\begin{array}{l}\text { Yaş grubunuz } \\
\text { nedir? }\end{array}$} & $25-34$ & 59 & 32 & 38 & 129 \\
\cline { 2 - 6 } & $35-44$ & 50 & 22 & 21 & 93 \\
\cline { 2 - 6 } & $45-54$ & 25 & 41 & 24 & 90 \\
\hline \multicolumn{2}{|c|}{ Total } & 134 & 95 & 83 & 312 \\
\hline
\end{tabular}

Oluşturulan çapraz tabloya göre Bireysel Emeklilik Sistemi'ni ilk defa duymayan 312 kişi içerisinde; 129 kişi 25-34 yaş grubunda, 93 kişi 35-44 yaş grubunda, 90 kişi 45-54 yaş grubundadır. Belirtilen yaş guruplarında bulunan kişilerin Bireysel Emeklilik Sistemi'ne katılım durumları şöyledir;

25-34 yaş grubundaki 129 kişi içerisinde; 59 kişi sistemde kalmayı sürdürürken, 38 kişi sisteme katılıp daha sonra ayrılmış ve 32 kişi ise sisteme hiç katılmamıştır.

35-44 yaş grubundaki 93 kişi içerisinde; 50 kişi sistemde kalmayı sürdürürken, 21 kişi sisteme katılıp daha sonra ayrılmış ve 22 kişi ise sisteme hiç katılmamıştır. 
45-54 yaş grubundaki 90 kişi içerisinde; 25 kişi sistemde kalmayı sürdürürken, 24 kişi sisteme katılıp daha sonra ayrılmış ve 41 kişi ise sisteme hiç katılmamıştır.

Bireysel Emeklilik Sistemi'ne katılım durumunun, içinde bulunulan yaş grubu ile ilgili olup olmadığını anlamak için kurulan $\mathrm{H}_{0}$ ve $\mathrm{H}_{1}$ hipotezleri ile bu hipoteze ait Ki-Kare Testi tablosu şöyledir;

$\mathrm{H}_{0}$ : Değişkenler arasında ilişki yoktur.

$\mathrm{H}_{1}$ : Değişkenler arasında ilişki vardır.

Tablo 6. Yaş Grubuna Göre Bireysel Emekliliğine Katılım Durumu Ki-Kare Testi.

\begin{tabular}{|l|r|r|r|}
\hline & Value & Df & Asymp. Sig. (2-sided) \\
\hline Pearson Chi-Square & $18,054^{\mathrm{a}}$ & 4 &, 001 \\
Likelihood Ratio & 17,882 & 4 &, 001 \\
Linear-by-Linear Association & 1,292 & 1 &, 256 \\
N of Valid Cases & 312 & & \\
\hline
\end{tabular}

a. 0 cells $(0,0 \%)$ have expected count less than 5 . The minimum expected count is 23,94.

Tablo 6'da gösterilen Ki-Kare Testi sonucuna göre 5'ten küçük hücre bulunmamaktadır. Söz konusu hipotez için Pearson Ki-Kare değeri olarak saptanan 0,001 değeri 0,05'ten küçük olduğu için $\mathrm{H}_{0}$ hipotezi reddedilir.

4.5. H4: Bireysel Emeklilik Sistemi'ne Katılım Durumu Eğitim Seviyesi ile Ilgilidir.

Eğitim durumuna göre Bireysel Emeklilik Sistemi'ne katılım durumunu ifade eden çapraz tablo şöyledir;

Tablo 7. Eğitim Durumu ve Bireysel Emeklilik Sistemi'ne Katılım Durumu

\begin{tabular}{|c|c|c|c|c|c|}
\hline & & \multicolumn{3}{|c|}{$\begin{array}{l}\text { Bireysel Emeklilik Sistemi’ne katılım } \\
\text { durumunuz nedir? }\end{array}$} & \multirow{2}{*}{ Total } \\
\hline & & Katılımcıyım & \begin{tabular}{c|} 
Hiç \\
katılmadım
\end{tabular} & $\begin{array}{l}\text { Katılimciydim, } \\
\text { ayrildım }\end{array}$ & \\
\hline \multirow{5}{*}{$\begin{array}{l}\text { Eğitim } \\
\text { durumunuz } \\
\text { nedir? }\end{array}$} & İlkokul & 6 & 9 & 5 & 20 \\
\hline & Lise & 24 & 35 & 30 & 89 \\
\hline & Ön lisans & 32 & 18 & 19 & 69 \\
\hline & Lisans & 45 & 20 & 18 & 83 \\
\hline & Lisansüstü & 27 & 13 & 11 & 51 \\
\hline \multicolumn{2}{|c|}{ Total } & 134 & 95 & 83 & 312 \\
\hline
\end{tabular}

Çapraz tablo üzerinde de görüldüğü gibi, Bireysel Emeklilik Sistemi’ni tanıyan kişilerin 20'si ilkokul mezunu, 89'u lise mezunu, 69'u ön lisans mezunu, 83 'ü lisans mezunu ve 51 kişi ise lisansüstü eğitim seviyesi mezunudur. Belirtilen eğitim derecelerinin Bireysel Emeklilik Sistemi'ne dağılımı şöyledir;

İlkokul mezunu 20 kişi içerisinde; 6 kişi sistemde kalmayı sürdürürken, 5 kişi sisteme katılmış daha sonra ayrılmış ve 9 kişi sisteme hiç katılmamıştır. 
Bireysel Emeklilik Sistemi'nde Kalma Tercihini Etkileyen Faktörlerin İncelenmesi: Erzurum Il Örneği

Lise mezunu 89 kişi içerisinde; 24 kişi sistemde kalmayı sürdürürken, 30 kişi sisteme katılmış daha sonra ayrılmış ve 35 kişi sisteme hiç katılmamıştır.

Ön lisans mezunu 69 kişi içerisinde; 32 kişi sistemde kalmayı sürdürürken, 19 kişi sisteme katılmış daha sonra ayrılmış ve 18 kişi sisteme hiç katılmamıştır.

Lisans mezunu 83 içerisinde; 45 kişi sistemde kalmayı sürdürürken, 18 kişi sisteme katılmış daha sonra ayrılmış ve 20 kişi sisteme hiç katılmamıştır.

Lisansüstü mezunu 51 içerisinde; 27 kişi sistemde kalmayı sürdürürken, 11 kişi sisteme katılmış daha sonra ayrılmış ve 13 kişi sisteme hiç katılmamıştır.

Bireysel Emeklilik Sistemi'ne katılımın eğitim durumu ile ilgili olup olmadığını anlamak için kurulan $\mathrm{H}_{0}$ ve $\mathrm{H}_{1}$ hipotezleri ile Ki-Kare Testi tablosu şöyledir;

$\mathrm{H}_{0}$ : Değişkenler arasında ilişki yoktur.

$\mathrm{H}_{1}$ : Değiş̧kenler arasında ilişki vardır.

Tablo 8. Eğitim Durumu ve Bireysel Emekliliğe Katılım Durumu Ki-Kare Tablosu.

\begin{tabular}{|l|r|r|r|}
\hline & Value & Df & Asymp. Sig. (2-sided) \\
\hline Pearson Chi-Square & $18,510^{\mathrm{a}}$ & 8 &, 018 \\
Likelihood Ratio & 18,849 & 8 &, 016 \\
Linear-by-Linear Association & 9,690 & 1 &, 002 \\
N of Valid Cases & 312 & & \\
\hline
\end{tabular}

a. 0 cells $(0,0 \%)$ have expected count less than 5 . The minimum expected count is 5,32.

Tablo 8'de gösterilen Ki-Kare Testi sonucuna göre 5'ten küçük olan hücre bulunmamaktadır ve bu durumda Pearson Ki-Kare değerine bakılır. Söz konusu hipotez için Pearson Ki-Kare hücresindeki 0,018'lik değer 0,05'ten küçük olduğu için $\mathrm{H}_{0}$ hipotezi reddedilir. Bu nedenle, Bireysel Emeklilik Sistemi'ne katılım durumunun eğitim seviyesi ile ilgili olduğu gözlenir.

4.6. H5: Bireysel Emeklilik Sistemi'ne Katılım Durumu Medeni Durum ile Illgilidir.

Medeni duruma göre Bireysel Emeklilik Sistemi'ne katılım durumunun gösteren çapraz tablo şöyledir;

Tablo 9. Medeni Durum ve Bireysel Emeklilik Sistemi'ne Katılım Durumu.

\begin{tabular}{|l|l|c|c|c|c|}
\hline \multirow{2}{*}{} & \multicolumn{3}{|c|}{$\begin{array}{c}\text { Bireysel Emeklilik Sistemi’ne katılım } \\
\text { durumunuz nedir? }\end{array}$} & \multirow{2}{*}{ Total } \\
\cline { 3 - 6 } & Katılımcıyım & $\begin{array}{c}\text { Hiç } \\
\text { katılmadım }\end{array}$ & $\begin{array}{c}\text { Katılımcıydım, } \\
\text { ayrıldım }\end{array}$ & \\
\hline \multirow{3}{*}{$\begin{array}{l}\text { Medeni durumunuz } \\
\text { nedir? }\end{array}$} & Evli & 71 & 59 & 47 & 177 \\
\cline { 2 - 6 } & Bekâr & 54 & 33 & 30 & 117 \\
\cline { 2 - 6 } & Dul & 9 & 3 & 6 & 18 \\
\hline \multicolumn{2}{|c|}{ Total } & 134 & 95 & 83 & 312 \\
\hline
\end{tabular}

Bireysel Emeklilik Sistemi'nden haberdar olan 312 kişi içerisinde; 177 kişi evli, 117 kişi bekâr ve 18 kişi ise duldur. Belirtilen nicelikteki kişi gruplarının Bireysel Emeklilik Sistemi'ne katılım durumları ise şöyledir; 
Evli olan 177 kişi içerisinde; 71 kişi sistemde kalmayı sürdürürken, 47 kişi sisteme katılıp daha sonra ayrılmış ve geri kalan 59 kişi sisteme hiç katılmamıştır.

Bekâr olan 117 kişi içerisinde; 54 kişi sistemde kalmayı sürdürürken, 30 kişi sisteme katılıp daha sonra ayrılmış ve geri kalan 33 kişi sisteme hiç katılmamıştır.

Dul olan 18 kişi içerisinde; 9 kişi sistemde kalmayı sürdürürken, 6 kişi sisteme katılıp daha sonra ayrılmış ve geri kalan 3 kişi sisteme hiç katılmamıştır.

Bireysel Emeklilik Sistemi'ne katılım durumunun, medeni durum ile ilgili olup olmadığını anlamak için kurulan bu hipoteze ait $\mathrm{H}_{0}$ ve $\mathrm{H}_{1}$ hipotezleri ile KiKare Testi tablosu şöyledir;

$\mathrm{H}_{0}$ : Değişkenler arasında ilişki yoktur.

$\mathrm{H}_{1}$ : Değiş̧kenler arasında ilişki vardır.

Tablo 10. Medeni Durum ve Bireysel Emeklilik Sistemi'ne Katılım Durumu Ki-Kare Testi.

\begin{tabular}{|l|r|r|r|}
\hline & Value & Df & Asymp. Sig. (2-sided) \\
\hline Pearson Chi-Square & $2,967^{\mathrm{a}}$ & 4 &, 563 \\
Likelihood Ratio & 3,148 & 4 &, 533 \\
Linear-by-Linear Association &, 326 & 1 &, 568 \\
N of Valid Cases & 312 & & \\
\hline
\end{tabular}

a. 1 cells $(11,1 \%)$ have expected count less than 5 . The minimum expected count is 4,79.

Tablo 10'da gösterilen Ki-Kare Testi sonucuna göre 1 hücrenin değeri 5 'ten küçüktür ve bu durumda Pearson Ki-Kare değerine bakılır. Ki-Kare Testi tablosunda bulunan 0,563 'lük değer 0,05 'ten büyük olduğu için $\mathrm{H}_{0}$ hipotezi kabul edilir. Dolayısıyla Bireysel Emeklilik Sistemi'ne katılım durumunun, medeni durum ile ilişkisi olmadığ gözlenir.

\section{Sonuç}

İnsan olmanın gereği olarak işsizlik, yaşlılık, malullük gibi gelirde azalmaya yol açabilecek bazı olası durumlar nedeniyle sosyal tehlikelerle karşı karşıya kalma ihtimali oldukça yüksektir. Bu bağlamda Bireysel Emeklilik Sistemi, kişilerin sahip oldukları tasarrufları piyasalara aktararak yatırım projelerinin desteklenmesine, üretimin artmasına, işsizliğin azalmasına ve yeni tasarrufların oluşmasına yardımcı olarak finansal sistem içerisinde önemli bir rol oynamaktadır.

Bireysel Emeklilik Sistemi'ne Erzurum'da yaşayan ve 25-54 yaş aralığında bulunan kişilerin bakış açısını ve sisteme halen katılımcı olanların görüşlerini belirlemeye yönelik olarak gerçekleştirilen çalışmanın bulguları şöyledir;

Bireysel Emeklilik Sistemi'nden \%81,46'l1k kesim haberdardır. Bireysel Emeklilik Sistemi'nden haberdar olma şeklinde; kişilerin ekonomi gündemini takip etme durumları, teknolojiye olan ilgi seviyeleri, haberleri öğrenme tercihleri, meslekleri, çevrelerindeki insanların sisteme dair tecrübe veya fikirleri, eğitim seviyeleri gibi etkenler rol oynamaktadır. 
Bireysel Emeklilik Sistemi'nde Kalma Tercihini Etkileyen Faktörlerin İncelenmesi: Erzurum Il Örneği

Bireysel Emeklilik Sistemi'nden haberdar olan kişiler içerisinde, \%36,22'lik kesim sistemin geleceğe katkıda bulunacağına inanmaktadır. Bireysel Emeklilik Sistemi ile gelecek kaygısı arasındaki ilişkide, kişilerin gelecek anlayışı ve gelecekten beklentileri, gelir durumları, yaşları, medeni durumları, bakımından sorumlu olduğu kişi sayısı gibi etkenler rol oynasa da belirtilen etkenler içerisinde en önemlisi yaş faktörüdür. Çünkü genç yaşta sisteme katılıp, 10 yıl süreli katkı paylarını aksatmadan yatıran bir kişinin sistemden emekli olacağı 56 yaşına kadar olan süre ile, orta yaşta sisteme dahil olup belki de 10 y1llık prim süresi sonunda 56 yaşını doldurmuş olacak bir kişinin sistemden beklentileri farklıdır.

Bireysel Emeklilik Sistemi'nden haberdar olan kişiler içerisinde, $\% 42,95^{\prime}$ lik kesim sisteme katılmayı sürdürmektedir. Sonucun bu şekilde ortaya çıkmasında Bireysel Emeklilik Sistemi'nin gönüllülük esasına dayanması, kişilerin mesleklerine göre eğer kamuda veya özel sektörde çalışıorlarsa sisteme Otomatik Katılım Sistemi ile dahil edilmeleri, yaşları, medeni durumları, sisteme ilişkin ön yargı veya tecrübeleri, çevrelerindeki insanların sisteme ilişkin tutumları, tasarruf arzu ve yetenekleri ile tasarruflarını değerlendirmek istedikleri yatırım araçları gibi faktörler rol oynamaktadır.

Bireysel Emeklilik Sistemi'nde halen katılımcı olan kişilerin \%66,42'si isteğe bağlı, \%33,58'i Otomatik Katılım Sistemi kapsamında hizmet almaktadır. Kişilerin meslekleri, gelir seviyeleri Bireysel Emeklilik Sistemi hakkındaki görüş ve tercihleri, devam etmek istedikleri emeklilik sözleşmeleri bu durumun ortaya çıkmasında önemli rol oynamaktadır.

Bireysel Emeklilik Sistemi'nde sisteme katılmayı sürdüren kişilerin \%55,22'si sistemden ayrılmayı düşünmektedir. Bu sonucun oluşmasında, kişilerin çalışma durumları, gelir ve giderlerinde meydana gelen değişimler, tüketim eğilimleri, ortaya çıkan ihtiyaçları, sistemden kaynaklanan sorunlar gibi parametreler önemli rol oynamaktadır.

Bireysel Emeklilik Sistemi'nde, sisteme katılmayı sürdüren kişilerin $\% 17,91$ 'i sistemi ideal bir yatırım aracı olarak görmektedir. Bu sonucun ortaya çıkmasında katılımcıların bireysel emeklilikten beklentileri ve bu beklentileri karşılama durumları, tasarruf eğilimleri, yatırım aracı tercihleri, mevcut diğer yatırımları ile bireysel emeklilik uygulamasının getirilerini kıyaslamalarının sonucu, yakın çevreleri gibi etkenler rol oynamaktadır.

Bireysel Emeklilik Sistemi'ne aktif katılımcı olan kişilerin \%8,96's1 vergi teşviklerini sistemden ayrılmamak için yeterli görmektedir. Bu durumun ortaya çıkmasında uygulanan vergi teşviklerinin katılımcılar tarafından bilinme durumu veya katılımcıların bekledikleri vergi teşviklerinin, var olan teşviklerden daha üst seviyede olması gibi etkenler rol oynamaktadır.

Bireysel Emeklilik Sistemi'ne aktif katılımcı olan kişilerin \%51,49'u istenildiği zaman ayrılma özelliğini sistemden ayrılmamak için geçerli bir sebep olarak görmektedir. Bu durumun ortaya çıkmasında, kişilerin sistemle ilgili 
görüşleri, sistemi tanıma düzeyleri, sistemden ayrılma konusundaki düşünceleri, sistemde geçirdikleri yıl sayısı önemli etkenlerdendir.

Bireysel Emeklilik Sistemi'ne aktif katılımc1 olan kişilerin \%35,07'si emeklilik döneminde ek gelir sağlama özelliğini sistemden ayrılmamak için yeterli görmektedir. $\mathrm{Bu}$ sonucun ortaya çıkmasında sisteme katılan kişilerin yaşları, emeklilik dönemlerine ilişkin beklentileri, aylık gelir miktarı, bakmakla yükümlü oldukları kişi sayısı gibi etkenler önemli rol oynamaktadır.

Bireysel Emeklilik Sistemi'ne aktif katılımcı olan kişilerin \%38,06's1 sistemin çalışmayan kişileri de kapsaması özelliğini benimsemektedir. $\mathrm{Bu}$ durumun ortaya çıkmasında çalışmayan kişilerin sisteme bakışları, sisteme katılma durumları, katılımcıların medeni durumları, gelir seviyeleri, bireysel emekliliğe katılma yönündeki düşünceleri önemli rol oynamaktadır.

Bireysel Emeklilik Sistemi'ne aktif katılımcı olan kişilerin \%38,06's1 katkı payı miktarının istenildiği zaman değiştirilebilmesi özelliğini benimsemektedir. $\mathrm{Bu}$ sonucun ortaya çıkmasında sisteme katılımcı olan kişilerin katk1 payı miktarını değiştirme düşünce, istek ve ihtiyacında olmamaları gibi etkenler rol oynamaktadır.

Çalışmada, Erzurum ilinde yaşayan ve 25-54 yaş aralığında bulunan ve Bireysel Emeklilik Sistemi'nden haberdar olan kişilerin, Bireysel Emeklilik Sistemi'ne katılım durumlarının cinsiyet, çalışılan mesleğin sektörü, yaş grubu, eğitim seviyesi ve medeni durum ile ilgili olup olmadığını saptamak amaciyla hipotezler kurularak Ki-Kare Testi yardımıyla sınanmıştır. Elde edilen Ki-Kare Testi sonuçlarına göre; Bireysel Emeklilik Sistemi'ne katılım durumu sahip olunan meslek, içinde bulunulan yaş grubu ve sahip olunan eğitim seviyesi ile ilgilidir. Buna karşın, Bireysel Emeklilik Sistemi'ne katılım durumu cinsiyet ve kişilerin medeni durumları ile ilgili değildir.

\section{Kaynaklar}

Bireysel Emeklilik Tasarruf ve Yatırım Sistemi Kanununda Değişiklik Yapılmasına Dair Kanun. (2016, 25 Ağustos). Resmi Gazete (Say1: 29812). Erişim adresi: https://www.resmigazete.gov.tr/eskiler/2016/08/ 20160825-4.htm

Coşkun Özer, A., ve Gürel, H. (2014). Türkiye'de Bireysel Emeklilik Sistemi Bilgi Düzeyi Ve Bes'e Katılımda Devlet Katkısının Etkisi Üzerine Bir Araştırma. Mustafa Kemal Üniversitesi Sosyal Bilimler Enstitüsü Dergisi, 11 (27), 159-166. Retrieved from https://dergipark.org.tr/tr/pub/mkusbed/ issue/19573/208721

Curtis, K., ve Youngquist, S. (2013). Part 21: Categoric Analysis: Pearson ChiSquare Test. Basics of Research, 32(4), 179-180.

Çetin, I., ve Sevüktekin, M. (2015). Bursa'da Kişilerin Bireysel Emeklilik Sistemine Girişini Etkileyen Faktörler. Muhasebe ve Finansman Dergisi, (67), 171-192. Retrieved from https://dergipark.org.tr/tr/pub/mufad/issue/ $35658 / 396588$ 
Bireysel Emeklilik Sistemi'nde Kalma Tercihini Etkileyen Faktörlerin İncelenmesi: Erzurum Il Örneği

Çolak, E. (2014). Ki-Kare Bağımsızlık Analizi. 05 15, 2019 tarihinde http://eczacilik.anadolu.edu.tr/bolumSayfalari/belgeler/ecz2014\%2013_2 0140527094539.pdf adresinden alınd1.

Çömlekçi, İ., ve Gökmen, O. (2017). Bireysel Emeklilik Sistemine Katılmada Etkili Olan Faktörler: Tr42 Bölgesinde Bir Araştırma. Journal of International Social Research, 10(49), 579-588.

EGMa, (t.y.). Devlet Katkısı 03 13, 2013 tarihinde Emeklilik Gözetim Merkezi Web Sitesi: https://www.egm.org.tr/bireysel-emeklilik/devlet-katkisi/

EGMb, (t.y.). Otomatik Katılım Sistemi Nedir? 03 13, 2013 tarihinde Emeklilik Gözetim Merkezi Web Sitesi: https://www.egm.org.tr/otomatikkatilim/oks-nedir/ adresinden alındı.

Gülay, T., Işık, M., ve Öztürk, M. (2017). Türkiye'de Bireysel Emeklilik Sistemi ve Akademisyenlerin Otomatik Katılıma Bakış Açılarına İlişkin Bir Analiz: Süleyman Demirel Üniversitesi Örneği. İs ve Hayat, 3 (6), 179205. Retrieved from https://dergipark.org.tr/en/pub/isvehayat/issue/ $34275 / 378862$

Gülcan, N. (2017). Bireysel Emeklilik Sistemi Farkındalığı: Üniversite Öğrencilerine Yönelik Bir Araştırma. Mehmet Akif Ersoy Üniversitesi Sosyal Bilimler Enstitüsü Dergisi, 9 (21), 369-383. Retrieved from https://dergipark.org.tr/tr/pub/makusobed/issue/31480/316670

Güvercin, C. H. (2004). Sosyal Güvenlik Kavramı ve Türkiye'de Sosyal Güvenliğin Tarihçesi. Ankara Üniversitesi Tıp Fakültesi Mecmuası, 57(2), 89-95.

ILO, (t.y.). Social Security - International Labour Organization. 01 11, 2019 tarihinde International Labour Organization Web sitesi: https://www.ilo.org/wcmsp5/groups/public/---dgreports/--dcomm/documents/publication/wcms_067588.pdf adresinden alındı.

İşseveroğlu, G., ve Hatunoğlu, Z. (2002). Türkiye'de Bireysel Emeklilik Sisteminin Makro Ekonomik Dinamiklere Etkisi Kapsaminda Swot Analizi. Muhasebe ve Finans Dergisi, (56), 155-174. Retrieved from https://dergipark.org.tr/tr/pub/mufad/issue/35675/396852

Kocabıyık, T., ve Küçükçakal, Z. (2018). Türkiye'de Bireysel Emeklilik Sistemi ve Çalışanların Otomatik Katılımdan Ayrılma Nedenleri: Isparta İlinde Bir Uygulama. Journal of Life Economics, 5 (4), 233-254. Retrieved from https://dergipark.org.tr/en/pub/jlecon/article/532877

Mizrahi , R., ve Aracı, H. (2012). Sosyal Güvenlik Sorununa Alternatif Çözüm Olan Bireysel Emeklilik Sistemi Üzerine Bir Araştırma. İzmir SMMO Dayanışma Dergisi, 41-47.

Öğütgen, M. (2004). Bireysel Emeklilik Sistemi. Toprak İşveren Dergisi. 1-4.

Özer, Ö., ve Çınar, E. (2013). Bir Vakıf Üniversitesi Akademik Personelinin Bireysel Emeklilik Sistemine Bakış Açısının Değerlendirilmesi/ Evaluation Of A Foundation University Academic Personal Perspective To Private Pension System. Mustafa Kemal Üniversitesi Sosyal Bilimler 
Enstitüsü Dergisi, 9 (19), 75-88. Retrieved from https://dergipark.org.tr/tr/pub/mkusbed/issue/ 19551/208374

TÜIKK (t.y.). 04 29, 2019 tarihinde Türkiye İstatistik Kurumu Sinıflama Sunucusu: https://biruni.tuik.gov.tr/medas $/ ? \mathrm{kn}=95 \&$ locale=tr adresinden alındi.

Seyfullahoğulları, A., ve Demirhan, B. (2016). Bireysel Emeklilik Sistemine Katkıları Açısından Vergi Avantajı İle Devlet Katkısının Karşılaştırılması. Marmara Sosyal Araştırmalar Dergisi, 23-50.

Şataf, C., ve Yıldırım, O. (2019). Türkiye'de Bireysel Emeklilik Sistemi'nin (Bes) Algılanma Düzeyi: Ordu İli Örneği. Selçuk Üniversitesi Sosyal Bilimler Meslek Yüksekokulu Dergisi, 22 (2), 572-588. Retrieved from https://dergipark.org.tr/tr/pub/selcuksbmyd/issue/49087/590765

Şener, O., ve Akın, F. (2010). Özel Emeklilik Fonları ve Türkiye'de Bireylerin Bireysel Emeklilik Sistemine Giriş Kararlarını Etkileyen Faktörlerin Belirlenmesi Üzerine Bir Araştırma. Marmara Üniversitesi İktisadi ve İdari Bïlimler Fakültesi Dergisi, 29(2), 291-312. Retrieved from https://dergipark.org.tr/tr/pub/muiibd/issue/487/4478

Şenocak, H. (2009). Sosyal Güvenlik Sistemini Oluşturan Bileșenlerin Tarihi Süreç Işı ğında Değerlendirilmesi. Sosyal Siyaset Konferansları Dergisi, 0(56), 409-468. Retrieved from https://dergipark.org.tr/tr/pub/iusskd/ issue/886/9855

Tunal1, D. (2016). Anadolu Üniversitesi Akademik Personelinin Bireysel Emeklilik Sistemine Bakışı. Işsletme ve Íktisat Çalışmaları Dergisi, 4 (3), 98-105. Retrieved from https://dergipark.org.tr/tr/pub/iicder/issue/ $31653 / 347056$

Uluyol, O. (2019). Akademisyenlerin Yatırım Araçlarını Tanıma ve Bu Araçlara Yatırım Yapma Durumlarının İncelenmesi: Türkiye Uygulaması. $R \& S$ Research Studies Anatolia Journal, 2 (4), 1-20. Retrieved from https://dergipark.org.tr/tr/pub/rs/issue/42930/472355

Uzun, H., ve Arslan, B. (2018), Bireysel Emeklilik Sistemi Algisı, Firat Üniversitesi Harput Araştırmaları Dergisi, 5 (2), 117-135. Retrieved from https://dergipark.org.tr/tr/pub/had/issue/41510/500745

Ünal, S., Boz, D., ve Ataşer, A. (2019). Bireysel Emeklilik Sistemi Üyeliği ve Bazı Demografik Değişkenlerin Finansal Okuryazarlık ile İlişkisi. Sosyal Bilimler Metinleri, 2019 (2), 104-115. Retrieved from https://dergipark.org.tr/tr/pub/sbm/issue/50581/653522

Yemez, İ., ve Akdoğan, M. (2019). Bireysel Emeklilik Sistemi Satın Alma Tercihlerinin Demografik Değişkenlere Göre İncelenmesi. Cumhuriyet Üniversitesi İktisadi ve İdari Bilimler Dergisi, 20 (1), 104-118. Retrieved from https://dergipark.org.tr/tr/pub/cumuiibf/issue/45599/492596 